\title{
I-III-VI chalcogenide semiconductor nanocrystals: Synthesis, properties, and applications
}

\author{
Shiqi Li a , Xiaosheng Tang a, *, Zhigang Zang a, Yao Yao b, Zhiqiang Yao c, Haizheng Zhong d, \\ Bingkun Chen ${ }^{d}$ \\ a Key Laboratory of Optoelectronic Technology \& Systems (Ministry of Education), College of Optoeletronic Engineering, Chongqing University, Chongqing \\ 400044, China \\ b College of Communication Engineering, Chengdu University of Information Technology, Chengdu 610225, Sichuan, China \\ ' School of Materials Science and Engineering, Zhengzhou University, Zhengzhou 450001, Henan, China \\ d Beijing Key Laboratory of Nanophotonics and Ultrafine Optoelectronic Systems, School of Materials Science \& Engineering, Beijing Institute of Technolo- \\ gy, Beijing 100081, China
}

A R T I C L E I N F O

Article history:

Received 21 January 2018

Accepted 12 February 2018

Published 5 April 2018

\section{Keywords:}

I-III-VI nanocrystal

Synthesis method

Solar cell

Light emitting diode

Bioimaging

Photocatalysis

\begin{abstract}
A B S T R A C T
Colloidal semiconductor nanocrystals have been proven to be promising candidates for applications in low-cost and high-performance photovoltaics, bioimaging, and photocatalysis due to their novel size- and shape-dependent properties. Among the colloidal systems, I-III-VI semiconductor nanocrystals (NCs) have drawn much attention in the past few decades. Compared to binary NCs, ternary I-III-VI NCs not only exhibit low toxicity, but also a high performance similar to that of binary NCs. In this review, we mainly focus on the synthesis, properties, and applications of I-III-VI NCs. We summarize the major synthesis methods, analyze their photophysical and electronic properties, and highlight some of the latest applications of I-III-VI NCs in solar cells, light-emitting diodes, bioimaging, and photocatalysis. Finally, based on the information reviewed, we highlight the existing problems and challenges.
\end{abstract}

(C) 2018, Dalian Institute of Chemical Physics, Chinese Academy of Sciences. Published by Elsevier B.V. All rights reserved.

\section{Introduction}

It is well understood that the development of new functional materials is a major driving force for technological evolution in the modern society. Semiconductor nanocrystals (NCs) are one such type of materials that have been at the forefront of technological innovation in the recent past [1-10]. In semiconductor nanoparticles, a quantum confinement effect appears when the size of the semiconductor NCs is less than or equal to the Bohr radius [11-15]. The band gap of semiconductor NCs, such as $\mathrm{CdSe}$ and $\mathrm{PbSe}$, can be adjusted by changing the particle size $[16,17]$. Over the past several decades, the synthesis, proper- ties, and applications of II-VI, III-V, and IV-VI semiconductor NCs have been extensively studied [18,19]. However, a large number of traditional II-VI semiconductor nanoparticles contain environmentally unfriendly elements, such as $\mathrm{Hg}, \mathrm{Cd}$, and $\mathrm{Pb}$. These elements exert negative influences on both health and environment, which seriously restricts the application of semiconductor NCs containing such elements. Therefore, it is essential to explore nanomaterials consisting of eco-friendly and low-toxic elements. Recently, I-III-VI semiconductor NCs have attracted considerable attention owing to the fact that some of them can be greener and not as toxic as II-VI NCs; examples of I-III-VI NCs include $\mathrm{CuInX}_{2}(\mathrm{X}=\mathrm{S}$, Se, and Te) and

\footnotetext{
* Corresponding author. Tel: +86-18423440836; E-mail: xstang@cqu.edu.cn DOI: 10.1016/S1872-2067(18)63052-9 | http://www.sciencedirect.com/science/journal/18722067 | Chin. J. Catal., Vol. 39, No. 4, April 2018
} 
Table 1

Relationship between binary, ternary, and quaternary semiconductor NCs.

\begin{tabular}{lcc}
\hline Group & Example & Type \\
\hline II-VI & $\mathrm{CdSe}$ & Binary \\
I-III-VI & $\mathrm{CuInS}_{2}$ & Ternary \\
I-II-III-VI & $\mathrm{CuInZnS}$ & Quaternary \\
I-II-IV-VI & $\mathrm{Cu}_{4} \mathrm{ZnSnSe}_{4}$ & \\
\hline
\end{tabular}

$\mathrm{AgInX}_{2}(\mathrm{X}=\mathrm{S}$, Se, and Te). In addition, similar to II-VI NCs, they exhibit excellent optical characteristics. Valence equivalent substitution of II atoms with I and III atoms leads to I-III-VI ternary semiconductor NCs, while the valence equivalent substitution of III atoms with II, IV or II, II, III atoms leads to $\mathrm{I}_{2}$-II-IV-VI 4 and I-II-III-VI quaternary semiconductors, respectively (Table 1). Binary semiconductors contain two typical crystalline structures-zinc blende and wurtzite. Similar to binary semiconductors, some of these ternary and quaternary semiconductors exhibit zinc blende and wurtzite structures, while others exhibit a chalcopyrite or other structures. Most of them are direct-band gap semiconductor materials; the band gaps are listed in Table 2. The band gap of $\mathrm{CuInS}_{2}$ is $\sim 1.53 \mathrm{eV}$, while its absorption coefficient can be as large as $10^{-5} \mathrm{~cm}^{-1}$ [143], which makes them good candidates for solar cells. Solar cells based on semiconductor quantum dots are predicted to have a maximum attainable thermodynamic conversion efficiency of $66 \%$ [20], and PbS-based solar cells have been reported to achieve a certified efficiency of $8.55 \%$ [21]. Further, they are used in a wide range of applications, including quantum dot-based light-emitting diodes (QD-LEDs), photoelectric detectors, nonlinear optics, quantum information [22-25], and photocatalysis [144]. In particular, I-III-VI NCs have been widely explored for bioimaging, because of their low toxicity.

Torimoto and co-workers studied bulk ZnS-AgInS 2 (ZAIS) and $\mathrm{ZnS}$-CuInS 2 solid solutions and demonstrated that bandgap

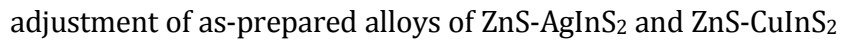
could be realized by changing the chemical composition. Moreover, they developed a facile method to synthesize color-adjustable luminophores, which were prepared by mixing sodium diethyldithiocarbamate in water with $\mathrm{AgNO}_{3}, \operatorname{In}\left(\mathrm{NO}_{3}\right)_{3}$, and $\mathrm{Zn}\left(\mathrm{NO}_{3}\right)_{2}$ at a mole ratio of $x: x: 2(1-x)$. The synthesized ZnS-AgInS 2 nanoparticles exhibited broad photoluminescence (PL) spectra and the emission color could be tuned from green to red depending on their chemical composition (Fig. 1) [2]. At

Table 2

Band gaps of I-III-VI semiconductor NCs.

\begin{tabular}{|c|c|c|c|}
\hline $\mathrm{CuBC}_{2}$ & Band gap $(\mathrm{eV})$ & $\mathrm{AgBC}_{2}$ & Band gap $(\mathrm{eV})$ \\
\hline $\mathrm{CuAlS}_{2}$ & 3.49 & $\mathrm{AgAlS}_{2}$ & 3.13 \\
\hline $\mathrm{CuGaS}_{2}$ & 2.43 & $\mathrm{AgGaS}_{2}$ & $2.51-2.73$ \\
\hline $\mathrm{CuInS}_{2}$ & 1.53 & $\mathrm{AgInS}_{2}$ & 1.87 \\
\hline $\mathrm{CuAlSe}_{2}$ & 2.67 & $\mathrm{AgAlSe}_{2}$ & 2.55 \\
\hline $\mathrm{CuGaSe}_{2}$ & 1.68 & $\mathrm{AgGaSe}_{2}$ & 1.83 \\
\hline $\mathrm{CuInSe}_{2}$ & 1.04 & $\mathrm{AgInSe}_{2}$ & 1.24 \\
\hline $\mathrm{CuAlTe}_{2}$ & 2.06 & $\mathrm{AgAlTe}_{2}$ & 2.27 \\
\hline $\mathrm{CuGaTe}_{2}$ & 1.23 & $\mathrm{AgGaTe}_{2}$ & $1.1-1.326$ \\
\hline $\mathrm{CuInTe}_{2}$ & $0.96-1.06$ & $\mathrm{AgInTe}_{2}$ & $0.96-1.04$ \\
\hline
\end{tabular}

the same time, this work provided an efficient method to prepare quaternary I-III-VI nanoparticles. Subsequently, Tang et al. [26] prepared CuInS2-ZnS alloy nanocubes with high luminescence using a solution-based diffusion method. Their results indicated that the bandgap of $\mathrm{CuInS}_{2}-\mathrm{ZnS}$ alloyed nanocubes could be adjusted by changing the ratio of $\mathrm{Zn} /(\mathrm{Cu}+\mathrm{In}+\mathrm{Zn})$. The CuInS 2 -ZnS alloyed NCs obtained in this work were highly crystalline and exhibited higher quantum yields (QYs) than pure CuInS2 NCs. Nowadays, a number of scientists are paying close attention to quaternary semiconductor NCs. Representatives of this class of materials include $\mathrm{Ag}(\mathrm{Cu}) \mathrm{InZnS}$ (AIZS, CIZS) and $\mathrm{Cu}$ (In, Ga)Se2 (CIGS) [27-29].

Through years of continuous efforts, various morphologies of NCs have been reported, such as nanowires, nanorods, nanoplates, and nanorings [30-33]. Shi et al. [27] demonstrated a facile route for synthesizing $\mathrm{CuInS}_{2}$ nanotubes. The nanotubes were made using an anodic aluminum oxide (AAO) template, which was highly oriented. The average diameter of these nanotubes was $20 \mathrm{~nm}$, which corresponded with the pore size of the AAO templates (Fig. 2). This particular work presented a more efficient and convenient approach to the synthesis of well-aligned one-dimensional nanostructured $\mathrm{CuInS}_{2}$ arrays using porous alumina templates as hard templates. Kolny-Olesiak and co-workers [145] studied the formation of $\mathrm{CuInS}_{2}$ under various reaction conditions. They obtained different shapes of $\mathrm{CuInS}_{2} \mathrm{NCs}$ by precisely controlling the ratio of the starting materials and it turned out that the shape mainly depends on three factors-the amount of technical grade

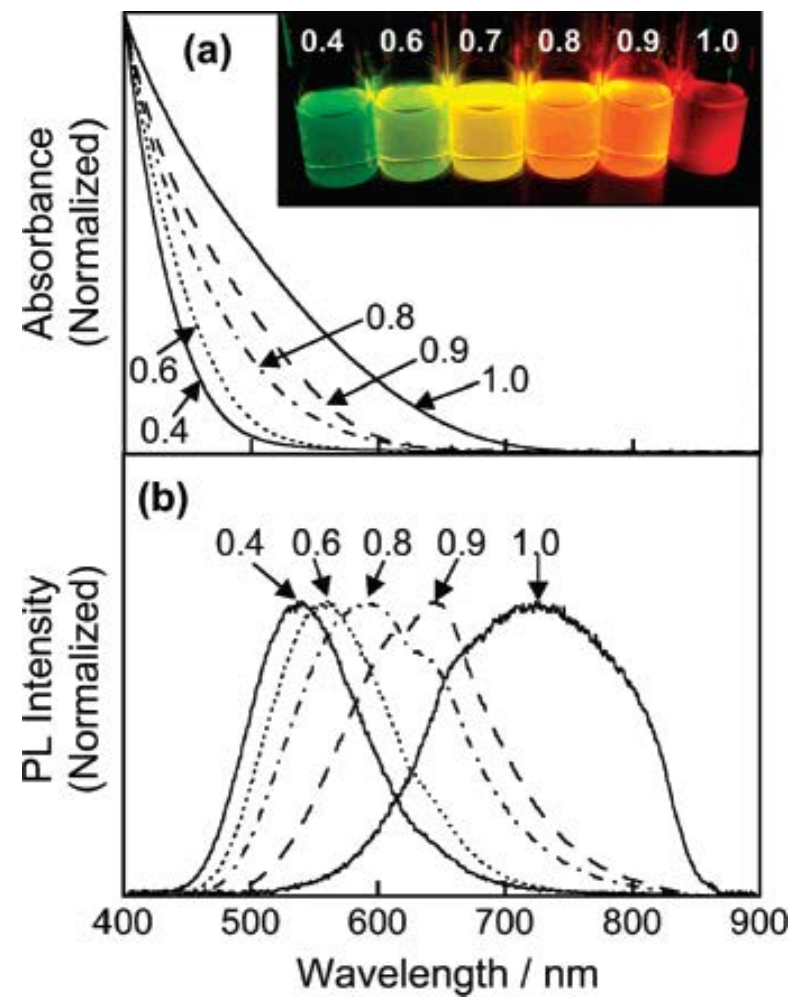

Fig. 1. Absorption spectra (a) and PL spectra (b) of ZAIS nanoparticles.

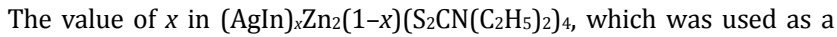
precursor, is indicated in the figure. The inset in panel (a) shows photographs of UV-illuminated ZAIS nanoparticle solutions [2]. 


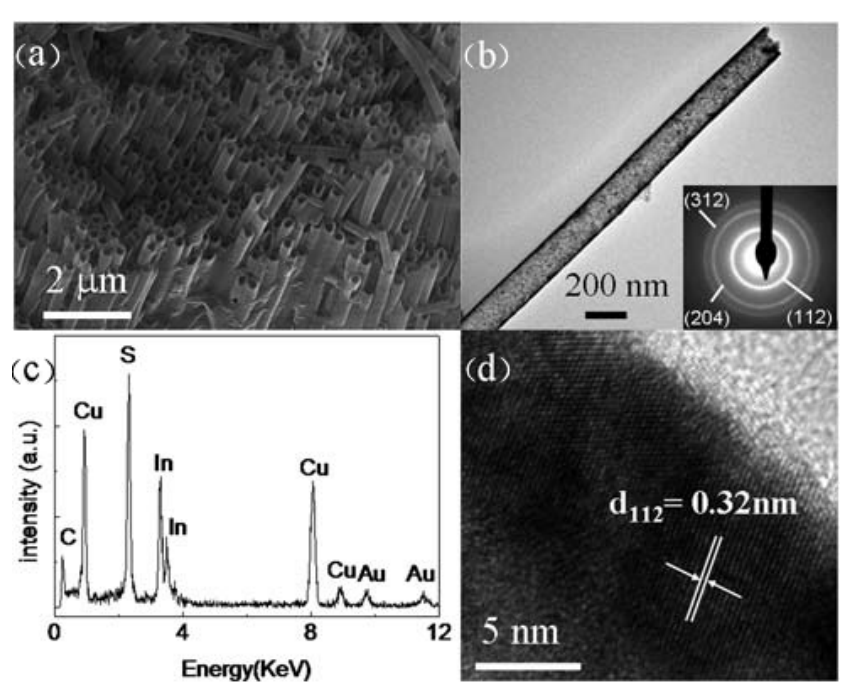

Fig. 2. Scanning electron microscope (SEM) (a), transmission electron microscopy (TEM) (b) (inset refers to the selected area electron diffraction (SAED) pattern), energy dispersive X-ray spectroscopy (EDX) spectrum (c), and high resolution transmission microscopy (HRTEM) image (d) of $\mathrm{CuInS}_{2}$ nanotubes [27].

trioctylphosphine oxide (TOPO) (regulating the activity of In monomers), the ratio between, 1-dodecanethiol (1-DDT) and $\mathrm{CuAc}$ (influencing the activity of $\mathrm{Cu}$ monomers), and the amount of $t$-DDT (mainly responsible for the sulfur supply for the reaction). According to the ratio between the starting materials, the amount of TOPO influenced the length of the particles. Higher amounts of TOPO led to shorter particles (Fig. 3(a) and (b)). Variation in the amount of both 1-DDT and $t$-DDT turned out to have a strong influence on the shape of the elongated particles. Increasing the amount of sulfur led to the formation of fish-shaped particles (Fig. 3(c)). Lower amounts of sulfur led to bottle-shaped $\mathrm{Cu}_{2} \mathrm{~S}-\mathrm{CuInS} \mathrm{S}_{2}$ hybrid particles (Fig. 3(d)). Further, the researchers studied the shape formation of $\mathrm{CuInS}_{2}$ exhaustively, providing a novel way to prepare NCs of different shapes.

In this review, we will firstly introduce the synthesis methods of I-III-VI semiconductor nanomaterials. Later, we will focus on their optical and electronic properties. Thirdly, applications based on I-III-VI semiconductor nanomaterials will be discussed. Finally, we will introduce the opportunities and challenges for I-III-VI semiconductor nanomaterials.

\section{Synthesis methods}

The number of studies on I-III-VI nanomaterials shows a rising trend. After more than ten years of continuous improvement, people have developed a variety of methods for the preparation of quantum dots, including the hot-injection method, non-injection method, thermal decomposition, and solvothermal route.

\subsection{Hot-injection method}

The hot-injection method was first reported by the Bawendi group in 1993 [3]. This method was initially used for the syn-

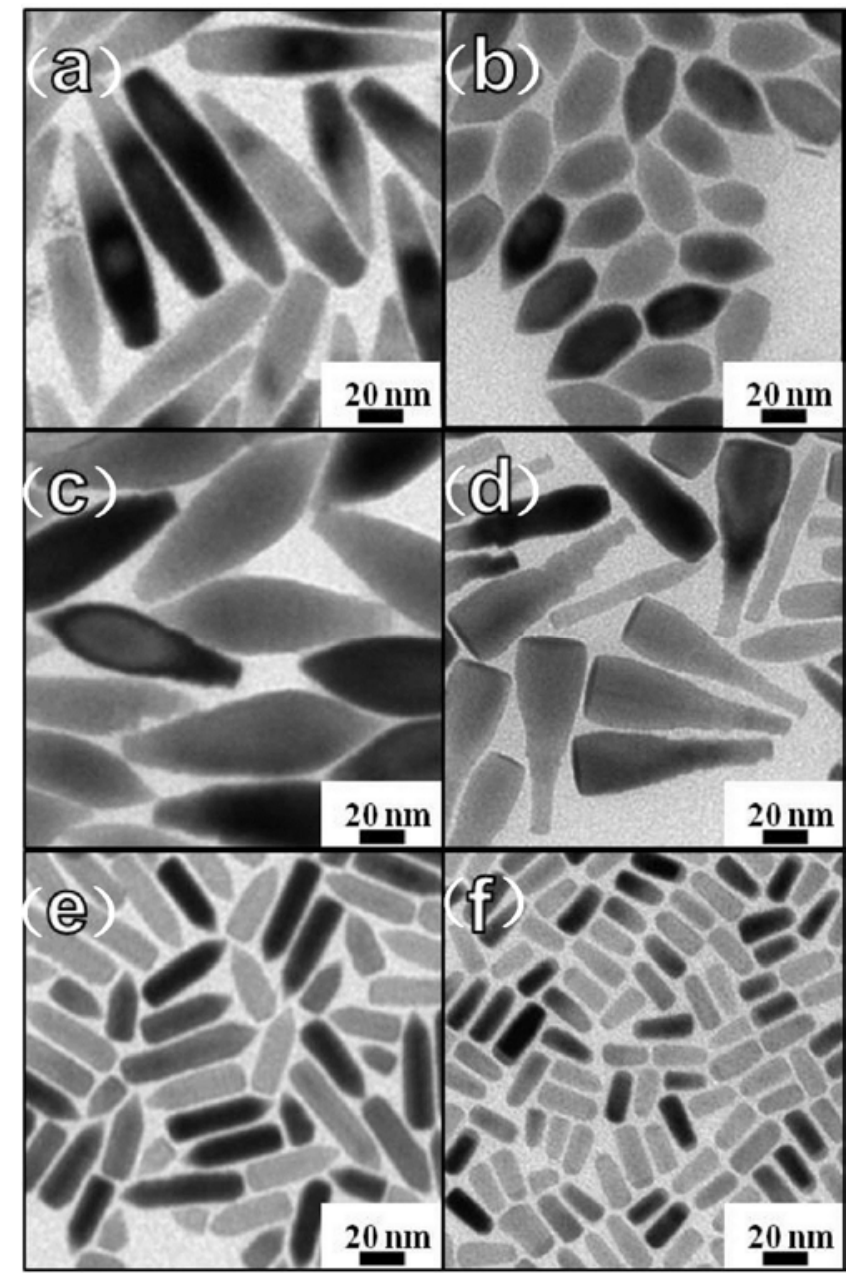

Fig. 3. Different aspect ratios of $\mathrm{CuInS}_{2}$ nanocrystals. Reaction conditions: (a) Cu:In:TOPO 1:1:4.4, $0.25 \mathrm{~mL}$ 1-DDT, $1.75 \mathrm{~mL} t$-DDT; (b) Cu:In:TOPO 1:1:10, $0.25 \mathrm{~mL}$ 1-DDT, $1.75 \mathrm{~mL} t$-DDT; (c) and (d) Cu:In:TOPO 1:1:3, $0.75 \mathrm{~mL}$ 1-DDT, $5.25 \mathrm{~mL} t$-DDT, image (d) shows an intermediate stage of the reaction; (e) and (f) Cu:In:TOPO 1:1:3.5, 0.5 $\mathrm{mL}$ 1-DDT, $1.5 \mathrm{~mL} t$-DDT; particles in image (f) were found in an aliquot taken during an early stage of the reaction conducted at a concentration twice that of (e) [145].

thesis of monodispersed cadmium chalcogenide QDs. The method to prepare NCs involved the injection of a "cold" (room temperature) solution of precursor molecules into another hot liquid reaction mixture. The injection leads to the instantaneous formation of the nuclei of NCs. Cooling the obtained NC nuclei prevents the formation of new nuclei [155]. For preparing monodisperse I-III-VI semiconductor nanoparticles, Tang et al. [4] studied the synthesis of Zn-doped $\mathrm{AgInS}_{2} \mathrm{NCs}$ using the hot-injection method. By changing the reaction temperature from 120 to $210{ }^{\circ} \mathrm{C}$, the amount of $\mathrm{Zn}$ in $\mathrm{AgInS}_{2}$ could be well controlled and the emission wavelength of the obtained $\mathrm{Zn}$-doped AgInS 2 NCs could be tuned from 680 to $520 \mathrm{~nm}$. TEM images showed that the obtained Zn-doped AgInS2 NCs were nearly spherical in morphology with a relatively narrow size distribution (Fig. 4). Moreover, Yang et al. [5] found that the "self-purification" effect in copper zinc tin sulfide (CZTS) NCs and stabilization of extra copper dopants were avoided by changing from one-pot synthesis to the hot-injection method. 
(a)

\begin{tabular}{|c|c|c|c|c|}
\hline Tem. & Ag & in & Zn & $\begin{array}{c}\mathrm{Zn} \\
\text { (Ag*in+Zn }\end{array}$ \\
\hline $120 \mathrm{C}$ & 0.0239 & 0.027 & 0.0295 & $36.4 \%$ \\
\hline $150 \mathrm{C}$ & 0.1453 & 0.1461 & 0.2039 & $41.2 \%$ \\
\hline $180 \mathrm{C}$ & 0.0356 & 0.0379 & 0.0723 & $49.8 \%$ \\
\hline $210 \mathrm{C}$ & 0.0927 & 0.0958 & 0.2445 & $56.5 \%$ \\
\hline
\end{tabular}

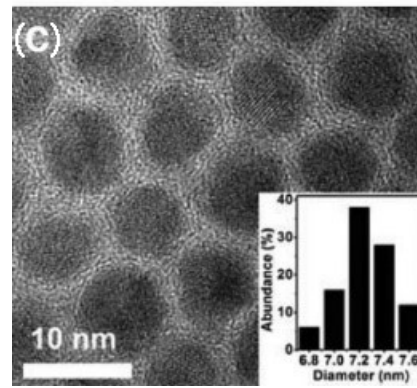

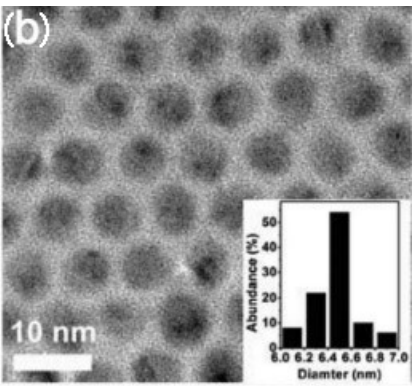

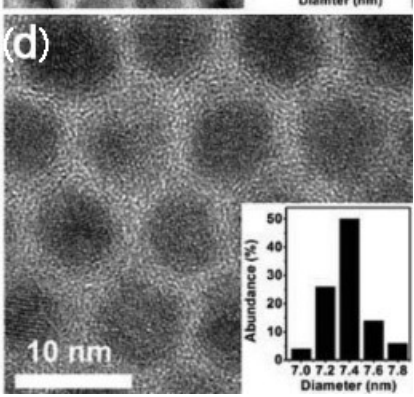

Fig. 4. Inductive coupled plasma emission (ICP) analysis (a) showing the chemical composition of $\mathrm{Zn}$-doped $\mathrm{AgInS}_{2}$ NCs prepared at different diffusion temperatures. TEM images of Zn-doped $\mathrm{AgInS}_{2}$ nanoparticles prepared at 150 (b), 180 (c), and $210^{\circ} \mathrm{C}(\mathrm{d})$, respectively (insets: histograms showing the size distribution of the NCs) [4]

As a result, the CZTS NCs prepared by the hot-injection method were more stable than those made using the one-pot synthetic route.

\subsection{Non-injection method}

Preparing NCs on a large scale using the hot-injection method is somewhat impractical. In order to precisely control the size, morphology, and element ratio, the non-injection method has become a more popular synthesis method. It can proceed at low temperatures. The precursors can be prepared in two or more steps and reacted by mixing them together at the proper temperature, after which NCs can be obtained. Zhong and co-workers studied a non-injection route to synthesize $\mathrm{CuInS}_{2}$ and obtained NCs with a triangular morphology and tunable band gap. In this study, $\mathrm{CuAc}, \operatorname{In}(\mathrm{Ac})_{3}$, and dodecanethiol reacted to form an intermediate complex and the solution was heated up till the generation of $\mathrm{CuInS}_{2} \mathrm{NCs}$. With an increase in the reaction time to 120 from $20 \mathrm{~min}$, the size of the $\mathrm{CuInS}_{2}$ NCs increased (3-8 nm). The aim of the non-injection method is to lower the reaction rate. A fast reaction between metal ions and dodecanethiol results in aggregation. In order to improve the previous results, researchers used $\mathrm{CuI}$ to replace $\mathrm{CuAc}$. $\mathrm{Cu}$ is a soft acid unlike Ac, which is a hard acid, whereas iodide and thiols (R-SH) are soft bases; the soft acid and soft base can bind more tightly than soft base and hard acid pairs. This improvement can lower the reaction rate between $\mathrm{Cu}$ and the $\mathrm{S}$ source [36].

\subsection{Thermal decomposition}

The thermal decomposition route is easy to operate and it has been successfully used to synthesize monodisperse NCs.
This method usually uses molecular single-source precursors and forms nanocrystals by controlling the temperature of thermal decomposition. Castro and co-workers [7] prepared nanometer-sized particles of chalcopyrite compounds $\mathrm{CuInS}_{2}$ and $\mathrm{CuInSe}_{2}$ by the thermal decomposition of molecular single-source precursors $\left(\mathrm{PPh}_{3}\right)_{2} \mathrm{CuIn}-(\mathrm{SEt})_{4}$ and $\left(\mathrm{PPh}_{3}\right)_{2} \mathrm{CuIn}(\mathrm{SePh})_{4}$. The reaction proceeded in a non-coordinating solvent, dioctyl phthalate, at temperatures between 200 and $300{ }^{\circ} \mathrm{C}$. For the preparation of CuInS2 nanocrystals, $\left(\mathrm{PPh}_{3}\right)_{2} \mathrm{CuIn}-(\mathrm{SEt})_{4}$ was added to the reaction flask and heating was resumed. The precursor dissolved at approximately $150^{\circ} \mathrm{C}$ and formed a transparent yellow solution. Upon increasing the temperature to $200{ }^{\circ} \mathrm{C}$, a red powder began to precipitate within a few minutes; a reaction time of $2 \mathrm{~h}$ was employed to complete the precipitation and maximize yield. After cooling to room temperature under an argon environment, the powder was isolated and consecutively washed with toluene and methanol, and was dried under vacuum at $60^{\circ} \mathrm{C}$. A portion of the red powder was placed in a flask containing fresh dioctyl phthalate and heated to 250 or $300{ }^{\circ} \mathrm{C}$ for $1 \mathrm{~h}$. A brown/black powder and black powder were obtained when the temperatures were 250 and $300{ }^{\circ} \mathrm{C}$, respectively. Each powder was washed and dried in the same manner before analysis. Both the brown/black powder and black powder were identified as nanocrystalline $\mathrm{CuInS}_{2}$.

\subsection{Solvothermal route}

The solvothermal route is another effective wet-chemical method for the synthesis of monodisperse semiconductor NCs. The solvothermal route involves high pressures. The selected temperature (sub- or supercritical domains) depends on the reactions required for obtaining the target material through the involved process [156]. Therefore, the solvothermal route usually uses an autoclave as the reaction vessel and the precursor materials are prepared and added into the autoclave for the reaction to occur. In addition, the solvothermal route does not need an $\mathrm{N}_{2}$ atmosphere or refluxing conditions, which makes it easier to operate compared to the hot-injection method. Yue et al. [20] studied a solvothermal route for the synthesis of zinc blende $\mathrm{CuInS}_{2}$. $\mathrm{CuCl}_{2}$ and $\mathrm{InCl}_{3} \cdot 4 \mathrm{H}_{2} \mathrm{O}$ were dissolved in absolute ethanol and stirred for $5 \mathrm{~min}$ at room temperature, leading to a blue solution, and transferred to a stainless steel autoclave and reacted at $200{ }^{\circ} \mathrm{C}$ for $16 \mathrm{~h}$. CuInS 2 QDs could be obtained by centrifugation and washing several times. This is the first time that zinc blende CuInS2 QDs were obtained by the solvothermal route; their average size was around $2-4 \mathrm{~nm}$, which verifies that the solvothermal route is a valid approach to prepare QDs.

Scientists usually prefer to use the thermal decomposition route to synthesize colloidal NCs. This method is scalable, reproducible, environmentally friendly, and cheap. A statistical table of the synthesis methods, chemistry, and characteristics of NCs is shown below (Table 3).

\subsection{Cation exchange and template synthesis}

In general, in the traditional methods, i.e., hot-injection 
Table 3

Overview of the chemical synthesis methods, chemistry, and characteristics of ternary and quaternary semiconductor NCs.

\begin{tabular}{|c|c|c|c|c|c|}
\hline Material & Structure & Chemistry & Method & Size/morphology & Ref. \\
\hline \multirow[t]{26}{*}{$\mathrm{CuInS}_{2}$} & \multirow[t]{14}{*}{$\mathrm{CH}$} & $\mathrm{Cu}(\mathrm{acac})_{2}, \mathrm{In}(\mathrm{acac})_{3}$, sulfur, OLA, DCB & $\mathrm{HJ}$ & 8-12 nm/spherical & [15] \\
\hline & & $\mathrm{Cu}(\mathrm{ac}), \operatorname{In}(\mathrm{ac})_{3}, \mathrm{DDT}, \mathrm{OA}, \mathrm{TOP}, \mathrm{ODE}$ & HU & 9-11.5 nm/cubic & [26] \\
\hline & & $\mathrm{Cu}(\mathrm{acac})_{2}, \operatorname{In}(\mathrm{acac})_{3}$, sulfur, DCB, OLA, AAO & $\mathrm{HU}$ & $200 \mathrm{~nm} /$ nanotubes & [27] \\
\hline & & $\mathrm{CuCl}, \mathrm{InCl}_{3}$, sulfur, DETA, AAO & HU & $200 \mathrm{~nm} /$ nanowires & [31] \\
\hline & & $\mathrm{CuSO}_{4} \cdot 5 \mathrm{H}_{2} \mathrm{O}, \mathrm{InCl}_{3} \cdot \mathrm{H}_{2} \mathrm{O}, \mathrm{CH}_{3} \mathrm{CSNH}_{2}$, ethanol & SR & $0.9-0.32 \mathrm{~nm} /$ nanosheets & [32] \\
\hline & & $\mathrm{Cu}(\mathrm{ac})_{2}, \operatorname{In}(\mathrm{ac})_{3}, \mathrm{DDT}, \mathrm{Sn}(\mathrm{ac})_{2} \mathrm{Cl}_{2}$ & $\mathrm{HU}$ & Polygonal & [34] \\
\hline & & CuI, InI 3 , sulfur, OLA, TOP, ODE & HU & $3-6 \mathrm{~nm}$ & [35] \\
\hline & & $\mathrm{CuCl}, \mathrm{InCl}_{3}, \mathrm{DDT},\left(\mathrm{NH}_{4}\right)_{2} \mathrm{~S}, \mathrm{OLA}$ & $\mathrm{HJ}$ & $1.61 \mathrm{~nm}$ & [37] \\
\hline & & $\mathrm{CuCl}, \mathrm{InCl}_{3}, \mathrm{OA}$, sulfur & SR & $3.5-4.3 \mathrm{~nm}$ & [38] \\
\hline & & $\mathrm{CuCl}_{2} \cdot 2 \mathrm{H}_{2} \mathrm{O}, \mathrm{InCl}_{3} \cdot 4 \mathrm{H}_{2} \mathrm{O}, \mathrm{MPA}, \mathrm{NaOH}, \mathrm{CS}\left(\mathrm{NH}_{2}\right)_{2}$ & HS & $2-4 \mathrm{~nm}$ & [39] \\
\hline & & $\mathrm{CuI}, \mathrm{In}(\mathrm{ac})_{3}, \mathrm{DDT}, \mathrm{MA}, \mathrm{ODE}$ & $\mathrm{HI}$ & $3 \mathrm{~nm}$ & [41] \\
\hline & & $\mathrm{CuCl}, \mathrm{InCl}_{3}$, sulfur, OLA & HU & $15-17 \mathrm{~nm} / \mathrm{spherical}$ & [42] \\
\hline & & $\mathrm{Cu}(\mathrm{ac}), \operatorname{In}\left(\mathrm{NO}_{3}\right)_{3}, \mathrm{TAA}, \mathrm{CTAB}, \mathrm{EG}$ & $\mathrm{HJ}$ & 80-100 nm/ spheres & [43] \\
\hline & & $\mathrm{CuCl}_{2}, \operatorname{In}\left(\mathrm{NO}_{3}\right)_{3}$, thiourea, benzyl alcohol & $\mathrm{HU}$ & $100-200 \mathrm{~nm} /$ cubes & [44] \\
\hline & \multirow[t]{8}{*}{ WZ } & $\mathrm{Cu}\left(\mathrm{NO}_{3}\right)_{2} \cdot 3 \mathrm{H}_{2} \mathrm{O}, \mathrm{In}\left(\mathrm{NO}_{3}\right)_{3} \cdot 4.5 \mathrm{H}_{2} \mathrm{O}, \mathrm{DDT}, \mathrm{OA}, \mathrm{OLA}$ & HU & $30-40 \mathrm{~nm} /$ various nanoparticles & [30] \\
\hline & & $\mathrm{Na}($ dedc $), \operatorname{In}\left(\mathrm{NO}_{3}\right)_{3}, \mathrm{Cu}(\text { dedc })_{2}, \mathrm{DDT}$, OLA & $\mathrm{HU}$ & $20-50 \mathrm{~nm} /$ nanowires & [33] \\
\hline & & $\mathrm{CuOAc}, \mathrm{InCl}_{3}$, thiourea, OLA, ODE, diphenyl ether, DDT, & $\mathrm{HJ}$ & $1.5 \mathrm{~nm} / \mathrm{spherical}$ & [47] \\
\hline & & $\mathrm{CuCl}_{2}, \mathrm{InCl}_{3}$, deionized water, TGA, $\mathrm{Na}_{2} \mathrm{~S}$ & HU & 20-30 nm & [48] \\
\hline & & $\mathrm{CuCl}, \mathrm{InCl}_{3}{ }_{4} \mathrm{H}_{2} \mathrm{O}, \mathrm{DDT}, \mathrm{OA}, \mathrm{ODE}$ & $\mathrm{HU}$ & $5 \mathrm{~nm} /$ hexagonal nanoplates & [49] \\
\hline & & $\mathrm{Cu}(\text { dedc })_{2}, \mathrm{Cu}(\mathrm{acac})_{2}, \mathrm{In}(\text { dedc })_{3}, \mathrm{DDT}, \mathrm{OA}$ & HU & $20-50 \mathrm{~nm} /$ nanoribbon & {$[50]$} \\
\hline & & $\mathrm{CuCl}, \mathrm{InCl}_{3}$, thiourea, DEG & HI & 80-100 nm/hexagonal plates & [51] \\
\hline & & $\mathrm{Cu}\left(\mathrm{NO}_{3}\right)_{2}, \mathrm{In}(\mathrm{ac})_{3}$, sulfur, OLA, DDT, OA, ODE & $\mathrm{HI}$ & $3-4 \mathrm{~nm}$ & [52] \\
\hline & \multirow[t]{3}{*}{$\mathrm{ZB}$} & $\mathrm{CuCl}, \mathrm{InCl}_{3}{ }_{4} \mathrm{H}_{2} \mathrm{O}, \mathrm{DDT}, \mathrm{OA}, \mathrm{ODE}$ & $\mathrm{HU}$ & $4.1 \mathrm{~nm} /$ triangular pyramids & [49] \\
\hline & & $\mathrm{CuCl}_{2}, \mathrm{InCl}_{3} \cdot{ }_{4} \mathrm{H}_{2} \mathrm{O}, \mathrm{HSPh}, \mathrm{Na}_{2} \mathrm{~S} \cdot 9 \mathrm{H}_{2} \mathrm{O}$ & SR & $2-4 \mathrm{~nm}$ & [20] \\
\hline & & CuI, $\mathrm{InCl}_{3}, \mathrm{TOOP}, \mathrm{TPOP}, \mathrm{OLA}, \mathrm{ODE}$ & $\mathrm{HU}$ & $5 \mathrm{~nm}$ & [54] \\
\hline & $\mathrm{CS}$ & $\mathrm{Cu}(\mathrm{ac})_{2} \cdot \mathrm{H}_{2} \mathrm{O}, \operatorname{In}(\mathrm{ac})_{3}, \mathrm{DMF}, \mathrm{TG}$ & $\mathrm{HJ}$ & $2.2 \mathrm{~nm} / \mathrm{spherical}$ & [56] \\
\hline \multirow[t]{8}{*}{$\mathrm{CuInSe}_{2}$} & \multirow[t]{6}{*}{$\mathrm{CH}$} & Selenium shot, TOP, CuI, TOOP, ODE, $\mathrm{InCl}_{3}, \mathrm{HDA}$ & HU & $1.2-5.6 \mathrm{~nm}$ & [57] \\
\hline & & $\mathrm{CuCl}, \mathrm{InCl}_{3}$, DT, ODE, selenium powder, TOP & $\mathrm{HU}$ & $2.3-6.2 \mathrm{~nm}$ & [58] \\
\hline & & $\mathrm{CuCl}_{2}, \mathrm{InCl}_{3}, \mathrm{Se}$ & $\mathrm{HU}$ & 3-6 nm X 30-80 nm/nanowhiskers & [59] \\
\hline & & $\mathrm{CuCl}, \mathrm{InCl}_{3}$, selenourea, OLA & HI & $7 \mathrm{~nm} / \mathrm{spherical}$ & [60] \\
\hline & & CuI, In(ac) $)_{3}$, Se, tributylphosphine, DDT, OA, ODE & HI & $3 \mathrm{~nm}$ & [61] \\
\hline & & $\mathrm{Cu}\left(\mathrm{O}_{2} \mathrm{CCH}_{3}\right), \operatorname{In}(\mathrm{O} 2 \mathrm{CCH} 3)_{3}, \mathrm{Se}, \mathrm{TOP}, \mathrm{OA}$ & $\mathrm{HI}$ & Nanowires and nanoparticals & [62] \\
\hline & WZ & $\mathrm{CuCl}, \mathrm{In}(\mathrm{ac})_{3}$, diphenylselenide, OLA & $\mathrm{HI}$ & $30 \mathrm{~nm} /$ polygonal & [63] \\
\hline & ZB & $\mathrm{CuCl}, \mathrm{InCl}_{3}$, selenourea, TOP, OLA, DDT, ODE & $\mathrm{HU}$ & 3-5 nm/triangular or spherical & [64] \\
\hline
\end{tabular}

(To be continued)

method, noninjection method, and solvothermal route, for preparing semiconductor NCs, it is difficult to control the chemical components and intermediate products. Therefore, in order to solve these problems, template synthesis through cation exchange has been developed and it allows for the fabrication of ternary and quaternary NCs. Zhong et al. [81] used a two-step template synthesis process to obtain CuInS2. Firstly, they heated a solution of $\mathrm{InCl}_{3}$, sulfur, and oleylamine to $215^{\circ} \mathrm{C}$ to generate $\operatorname{In}_{2} \mathrm{~S}_{3}$ nanoplates. Next, a copper precursor (CuI/DDT) was injected into the $\mathrm{In}_{2} \mathrm{~S}_{3}$ nanoplates solution to introduce copper ions; thus, $\mathrm{CuInS}_{2}$ nanoplates could be obtained. Zhang and co-workers [82] used CuS nanoplates as a template to successfully fabricate $\mathrm{CuInS}_{2}, \mathrm{CuIn}_{x} \mathrm{Ga}_{1-x} \mathrm{~S}_{2}$, and $\mathrm{Cu}_{2} \mathrm{ZnSnS}_{4} 2 \mathrm{D} \mathrm{NCs}$, with the same thickness, lateral dimensions, and hexagonal morphology. These obtained ternary and quaternary NCs exhibited the same morphology as with their binary template. Template synthesis offers a new direction to control the morphology and components for the synthesis of ternary and quaternary NCs, and it can enhance the efficiency of photovoltaic devices based on the solvothermal route.
Donega et al. [83] successfully used a cation exchange method to obtain $\mathrm{CuInS}_{2} \mathrm{NCs}$ using $\mathrm{Cu}_{2-x} \mathrm{~S}$ ( $x$ can be adjusted from 1 to 2) NCs. They developed a way a slow down the cation exchange process and obtained near-infrared region (NIR) $\mathrm{CuInS}_{2} \mathrm{NCs}$ for the first time. The cation exchange process is usually highly directional and maintains the crystal structure of the parent NCs and substructure of the cation, along with the cation exchange. ZnS NCs can be obtained through cation exchange based on $\mathrm{Cu}_{2-x} \mathrm{~S}$ NCs, and this process involves a complete replacement [84-86]. In these studies on $\mathrm{ZnS}$ NCs, the researchers replaced a portion of the $\mathrm{Cu}^{+}$ions with $\mathrm{In}^{+}$ions to generate $\mathrm{CuInS}_{2} \mathrm{NCs}$; hence, the exchange rate had to be precisely controlled. Lesnyak and co-workers [87] used $\mathrm{Cu}_{2} \mathrm{~S}$ as the parent NCs to fabricate CIZS NCs by adding $\mathrm{Zn}^{+}$and $\mathrm{In}^{+}$ions. We can also generate core/shell structure CIZS/ZnS NCs by introducing $\mathrm{Zn}^{+}$ions based on CuInS 2 parent NCs.

\subsection{Microfluidic systems}

Microfluidic systems are promising in generating NCs with 
Table 3 (continued)

\begin{tabular}{|c|c|c|c|c|c|}
\hline Material & Structure & Chemistry & Method & Size/morphology & Ref. \\
\hline \multirow[t]{2}{*}{$\mathrm{CuGaS}_{2}$} & $\mathrm{WZ}$ & $\mathrm{CuAc}, \mathrm{Ga}(\mathrm{acac})_{3}, 1$-DDT, ODE & HU & sphere & [65] \\
\hline & $\mathrm{CH}$ & $\mathrm{CuCl}, \mathrm{Ga}, \mathrm{S}$, water or benzene & $\mathrm{HU}$ & $35 \mathrm{~nm}$ & [66] \\
\hline $\mathrm{CuGaSe}_{2}$ & $\mathrm{CH}$ & $\mathrm{Cu}(\mathrm{ac})_{2}, \mathrm{Ga}(\mathrm{ac})_{3}, \mathrm{Se}$, OLA & $\mathrm{HI}$ & $11 \mathrm{~nm}$ & [67] \\
\hline \multirow[t]{2}{*}{ CuInSeS } & $\mathrm{CH}$ & $\mathrm{CuCl}_{2}, \mathrm{InCl}_{3}, \mathrm{~S}, \mathrm{Se}, \mathrm{EDA}$ & $\mathrm{HU}$ & $15 \mathrm{~nm} /$ aggregated & [68] \\
\hline & & $\mathrm{Cu}_{2} \mathrm{~S}, \mathrm{~S}$, hydrazine, $\mathrm{In}_{2} \mathrm{Se}_{3}, \mathrm{Se}$ & $\mathrm{HU}$ & $45 \mathrm{~nm}$ & [69] \\
\hline \multirow[t]{4}{*}{$\mathrm{AgInS}_{2}$} & $\mathrm{CH}$ & $\operatorname{Ag}(\mathrm{ac}), \operatorname{In}(\mathrm{ac})_{3}, \mathrm{~S}, \mathrm{DDT}, \mathrm{TOCA}$ & $\mathrm{HI}$ & $6 \mathrm{~nm} /$ triangular & [70] \\
\hline & & $\mathrm{AgNO}_{3}, \operatorname{In}(\mathrm{ac})_{3}, \mathrm{DDT}, \mathrm{OA}, \mathrm{TOP}, \mathrm{ODE}$ & HU & $5 \mathrm{~nm} / \mathrm{spherical}$ & [71] \\
\hline & & $\mathrm{AgNO}_{3}, \mathrm{InCl}_{3}, \mathrm{CS}_{2}, \mathrm{HDA}$, anisole & HI & $17 \mathrm{~nm} / \mathrm{rectangular}$ & [72] \\
\hline & $\mathrm{TG}$ & $\mathrm{AgNO}_{3}, \mathrm{InCl}_{3} \cdot{ }_{4} \mathrm{H}_{2} \mathrm{O}, \mathrm{DDT}$ & $\mathrm{HU}$ & $5 \mathrm{~nm} /$ flowerlike & [73] \\
\hline $\mathrm{CuIn}_{0.5} \mathrm{Ga}_{0.5} \mathrm{~S}_{2}$ & $\mathrm{CH}$ & $\mathrm{Cu}(\mathrm{Oac})_{2}, \mathrm{InCl}_{3}, \mathrm{GaCl}_{3}, \mathrm{Na}_{2} \mathrm{Se}, \mathrm{C}_{2} \mathrm{H}_{4} \mathrm{O}_{2} \mathrm{~S}$ & $\mathrm{HU}$ & $3 \mathrm{~nm}$ & [74] \\
\hline $\mathrm{CuIn}_{0.5} \mathrm{Ga}_{0.5} \mathrm{~S}_{2}$ & & $\begin{array}{c}\left(\mathrm{Ph}_{3} \mathrm{P}\right)_{2} \mathrm{Cu}(\mathrm{mSEt})_{2} \mathrm{In}(\mathrm{Set})_{2,}\left(\mathrm{Ph}_{3} \mathrm{P}\right)_{2} \mathrm{Cu}(\mathrm{mSEt})_{2} \mathrm{Ga}(\mathrm{Set})_{2} \text {, } \\
\text { 1,2-ethaneditiol, benzylacetate }\end{array}$ & $\mathrm{HU}$ & $3-4 \mathrm{~nm}$ & {$[45]$} \\
\hline AgInZnS & HA & $\mathrm{AgNO}_{3}, \operatorname{In}(\mathrm{Ac})_{3}, \mathrm{DDT}, \mathrm{OA}, \mathrm{ODE}, \mathrm{TOP}$, zinc stearate, sulfur, OLA & $\mathrm{HJ}$ & $20 \mathrm{~nm} /$ nanorod & {$[40]$} \\
\hline \multirow[t]{2}{*}{ CuInZnS } & $\mathrm{TG}$ & $\mathrm{Cu}\left(\mathrm{NO}_{3}\right)_{2}, \mathrm{InCl}_{3}, \mathrm{GSH}, \mathrm{Na}_{2} \mathrm{~S}, \mathrm{Zn}(\mathrm{Oac})$ & HU & $3.3 \mathrm{~nm}$ & [29] \\
\hline & & $\mathrm{Cu}(\mathrm{Oac})_{2}, \operatorname{In}(\mathrm{Oac}) 3$, sulfur, $\mathrm{Zn}(\mathrm{Oac})_{2}$, DDT, ODE & $\mathrm{HU}$ & $3.1 \mathrm{~nm}$ & {$[55]$} \\
\hline \multirow[t]{5}{*}{$\mathrm{Cu}_{2} \mathrm{ZnSnS}_{4}$} & KS & $\mathrm{CuCl}_{2}, \mathrm{ZnO}, \mathrm{SnCl}_{4}$, sulfur, OLA, ODE & $\mathrm{HU}$ & $15 \mathrm{~nm} /$ irregular & [76] \\
\hline & & $\mathrm{Cu}(\mathrm{ac})_{2}, \mathrm{Zn}(\mathrm{ac})_{2}, \mathrm{Sn}(\mathrm{ac})_{4}$, sulfur, OLA & $\mathrm{HU}$ & 5-6 nm/spherical & [77] \\
\hline & & $\mathrm{CuCl}_{2}, \mathrm{Zn}(\mathrm{ac})_{2}, \mathrm{SnCl}_{4}$, sulfur, EDA & $\mathrm{HU}$ & 5-32 nm/aggregated & [78] \\
\hline & WZ & $\mathrm{CuCl}_{2}, \mathrm{ZnCl}_{2}, \mathrm{SnCl}_{4}, \mathrm{DDT}, \mathrm{OLA}$ & $\mathrm{HJ}$ & $20 \mathrm{~nm} \times 28 \mathrm{~nm} /$ prisms & [79] \\
\hline & & $\mathrm{CuCl}_{2}, \mathrm{ZnCl}_{2}, \mathrm{SnCl}_{4}, \mathrm{DDT}, \mathrm{OA}$ & $\mathrm{HJ}$ & $14 \mathrm{~nm} /$ plates & [79] \\
\hline $\mathrm{Cu}_{2} \mathrm{ZnSnSe}_{4}$ & ST & $\mathrm{CuCl}_{2}, \mathrm{ZnCl}_{2}, \mathrm{SnCl}_{4}, \mathrm{Se}, \mathrm{OLA}, \mathrm{DDT}$ & $\mathrm{HI}$ & $3.4 \mathrm{~nm} / \mathrm{spherical}$ & [80] \\
\hline
\end{tabular}

CH: chalcopyrite, WZ: wurtzite, ZB: zinc blende, TG: tetragonal, HA: hexagonal, KS: kesterite, ST: stannite, HI: hot-injection, HU: heating-up, SR: solvothermal route, acac: acetylacetonate, OLA: Oleylamine, DCB: o-dichlorobenzene, ac: acetate, DDT: dodecanethiol, OA: oleic acid, TOP: tri-n-octylphosphine, ODE: octadecene, AAO: anodic aluminium oxid, DETA: anhydrous diethylenetriamine, MPA: mercaptopropionic acid, MA: myristic acid, TAA: thioacetamide, CTAB: cetyltrimethylammonium bromide, EG: ethylene glycol, dedc: diethyldithiocarbamate, TGA: thioglycolic acid, DEG: diethylene glycol, HSPh: 4-bromothiophenol, TOOP: trioctylphosphite, TPOP: triphenylphosphite, DMF: $n$, $n$-dimethylformamide, TG: 1-thioglycero, HDA: hexadecylamine, DT: $n$-dodecylthiol, EDA: ethylenediamine, TOCA: tri-n-octylamine, GSH: reduced glutathione.

complex chemical compositions [88]. The formation of core-shell structure NCs remains a complex undertaking since shell growth is ideally achieved by successive ion layer adhesion and reaction (SILAR), which requires core particle purification and its transfer to a second reactor for shell growth. Microfluidic systems can retain the same reactor to achieve the complex growth of NCs. A microfluidic system has many advantages, i.e., rapid mass and heat transfer in microfluidic environments, efficient decoupling of nucleation and growth stages, facile multi-step addition of reagents, and fast parametric screening of reaction parameters for rapid reaction optimization. DeMello and co-workers obtained core/shell structure CuInS/ZnS NCs using a two-stage microfluidic system designed by themselves. The microfluidic reaction consisted of two steps - the first step is the fabrication of the core and the second step is the fabrication of core/shell structure NCs. By injecting a $\mathrm{ZnS}$ single-source precursor into the droplets containing the $\mathrm{CuInS}_{2}$ core and without purification, they obtained a population of core-shell NCs emitting between 580 and $760 \mathrm{~nm}$ with a significantly narrow size distribution of 90-95 nm [89].

\section{Photophysical and electronic properties}

Based on the quantum confinement effect, I-III-VI semiconductors nanoparticles exhibit a tunable band gap; the spectra can be changed by controlling the size of NCs. The full width at half-maximum (FWHM) of PL emissions for CuInS2-ZnS NCs is almost three times greater than that of monodisperse CdSe NCs [90]. The phenomenon is also suitable for other I-III-VI NCs and
II-V NCs. In order to analyze the principle and determine whether size inhomogeneity influences broadened emission spectra, researchers carried out size-selective precipitation experiments. The FWHM of a single CuInSe 2 particle is $40 \mathrm{~nm}$ [91], which is much larger than that of single CdSe particles (13-18 nm) [92]. The result shows that the broadened emission spectra can be attributed mainly to the distribution of vibrational states. In comparison to II-VI NCs, I-III-VI NCs have larger Stokes shifts, which reduces self-absorption effects in light-emitting and bioimaging applications [91]. The bandgap of NCs can be adjusted by size, temperature, and chemical composition. The observed temperature-dependent, size-dependent, and energy-dependent energy shifts can be explained by a "donor-acceptor pair" (DAP) recombination mechanism [93]. Ternary and quaternary NCs have large quantities of nonstoichiometric compositions and complicated crystal structures; the internal defects play an important role in photoluminescence, because they were responsible for donor and acceptor states in ternary systems, such as the vacancies and interstitial atoms in $\mathrm{AgInS}_{2} \mathrm{NCs}$. Donor sites may include sulfur vacancies, interstitial Ag ions, and will replace Ag sites (antisite defects), while acceptors include Ag vacancies, interstitial In ions, and Ag replaces In sites. As a result, the photoluminescence mechanism depends on the exact stoichiometry and structure of the NCs [18]. With the inclusion of a fourth element implanted into the crystalline structure, a disorder is caused in the internal electronic states leading to a photoluminescence shift to a shorter wavelength, such as CuInS2-ZnS [94-96] and AgInS2-ZnS [97,98]. 

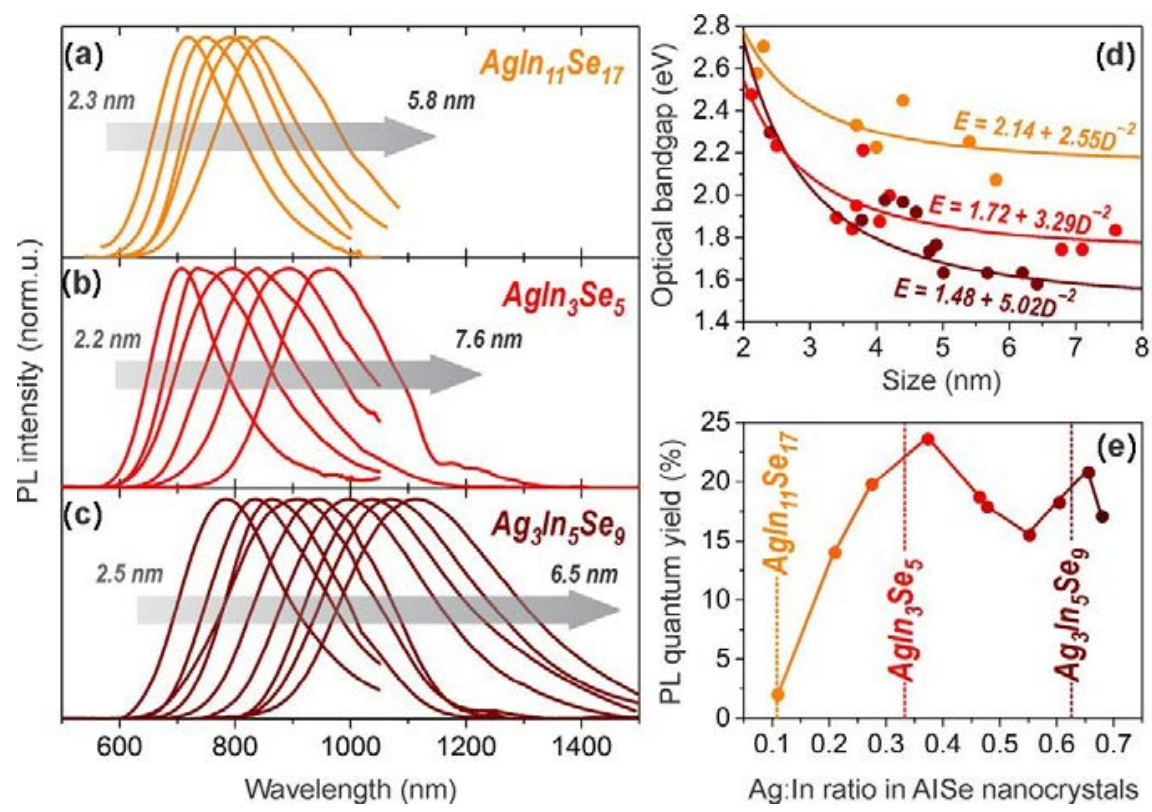

Fig. 5. Optical properties of three representative AISe nanocrystal compositions. (a-c) Size-dependent PL spectra; (d) Size dependence of optical band gaps; (e) Composition dependence of PL efficiency of 3-nm AISe NCs. In all the plots, the data corresponding to AgIn 11 Se 17 NCs are shown in orange, $\mathrm{AgIn}_{3} \mathrm{Se}_{5}$ in red, and $\mathrm{Ag}_{3} \mathrm{In}_{5} \mathrm{Se}_{9}$ in brown [100].

Macdonal and co-workers conducted a systematic study on the luminescence mechanism of wurtzite (WZ)-structure $\mathrm{CuInS}_{2}$. They developed organic surface passivation and inorganic surface passivation on $\mathrm{WZ} \mathrm{CuInS}_{2}$, in order to study the luminescence mechanism of defects. No substantial change in the spectral position or shape of the emission was observed in surface-passivated $\mathrm{WZ} \mathrm{CuInS}_{2}$ and emission originates from an internal defect [99]. Wood et al. [100] studied the luminescence properties of indium-rich AgInSe 2 (AISe) NCs. The AISe NCs maintain the same size of $3 \mathrm{~nm}$ and different QYs were observed upon changing the molar ratio of $[\mathrm{Ag}] /[\mathrm{In}]$ (Fig. 5). PLQYs range between $15 \%$ and $25 \%$ for all AISe compositions with Ag:In atomic ratios of $>0.25$, but drops notably for smaller Ag:In ratios. Two maxima in PLQY are apparent for NCs with Ag:In $=0.35$ and 0.65 . Since the concentration of silver vacancies monotonically increases toward lower Ag:In atomic ratios, the researchers concluded that the PLQY of AISe NCs in the composition range of Ag: $\mathrm{In}=0.35$ to 0.65 is not determined by the defect concentration, but rather by the distribution of defects within the crystal structure.

Moreover, emission wavelength and chemical composition can both influence the PL lifetimes of I-III-VI semiconductor NCs. The PL decays of I-III-VI NCs can usually be described by double- or triple-exponential analysis [91]. The longer component of hundreds of nanoseconds from double-exponential analysis was attributed to DAP recombination. The component of tens of nanoseconds was attributed to nonradiative recombination induced by surface defects. This was confirmed by the observation that surface treatment can suppress fast decays in I-III-VI NCs [23,80]. DAP recombination is the most remarkable mechanism influencing photophysical and electronic properties.

Crooker and co-workers [101] detected spin-exchange cou- pling between the paramagnetic moments of $\mathrm{CuInS}_{2} \mathrm{NCs}$ and the conduction/valence bands of the host lattice; both CIS and Cu:ZnSe NCs exhibit a substantial PL, but the phenomenon is not observed in CdSe thus far. It can be concluded that copper atoms will be incorporated as paramagnetic $\mathrm{Cu}^{2+}$ ions. In nonmagnetic semiconductors, such as $\mathrm{CdSe}$ and $\mathrm{ZnSe}$, magnetic flux
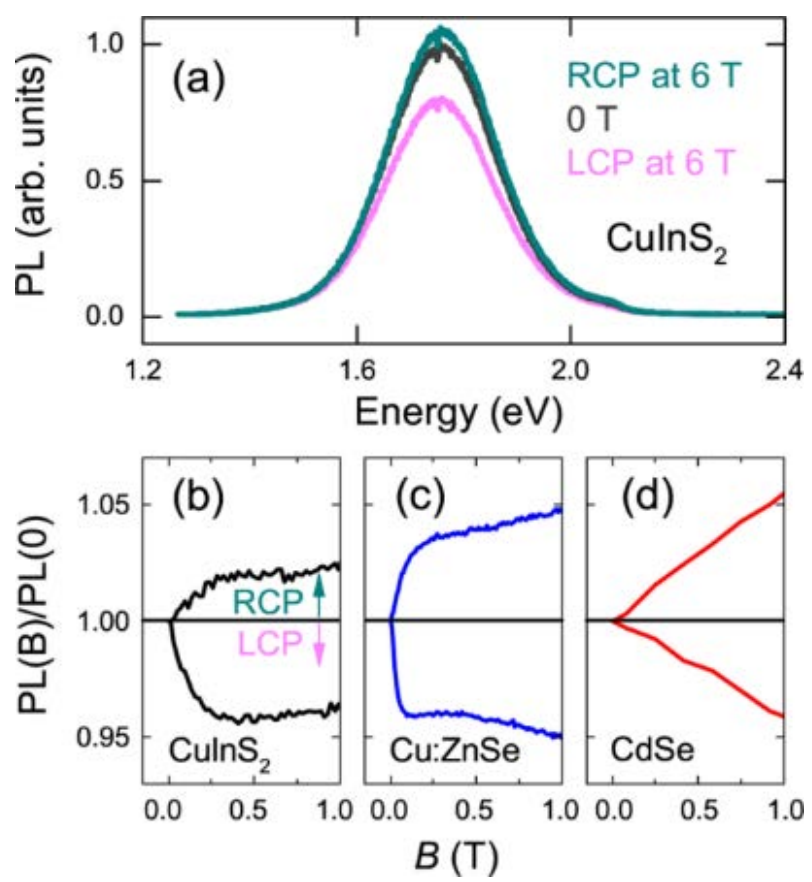

Fig. 6. (a) Polarization-dependent PL of right circularly polarized (RCP) (teal) and left circularly polarized (LCP) (pink) emission at B $=+6$ and 0 $\mathrm{T}$ (dark gray) for CIS NCs $(\mathrm{Cu} / \mathrm{In}=1.26)$. Integrated PL from 0 to $1 \mathrm{~T}$ for both RCP and LCP emission versus B for CIS (b), Cu:ZnSe (c), and CdSe (d) NCs at $3 \mathrm{~K}$ [101]. 
density $(B)$ generates a linear Zeeman splitting of the conduction and valence bands due to the intrinsic diamagnetism of the host semiconductor (Fig. 6(c) and (d)). In contrast, polarization-resolved emission from both CIS and Cu:ZnSe NCs exhibits a nonlinear behavior as a function of $B$ (Fig. 6(a) and (b)). These observations are consistent with the existence of localized paramagnetic states in the CIS bandgap and their important role in determining the PL from CIS NCs.

\section{Applications}

To date, semiconductor NCs have been widely applied in solar cells, LEDs, biolabeling, and drug delivery, due to their outstanding photophysical and electronic properties. A number of scientists tried to utilize these advantages to improve the performance of solar cells and LEDs. Their efforts may provide more benefits to us and promote the development of science.

\subsection{Solar cells}

Semiconductor NCs can be used as a "nanocrystal ink" to prepare absorbance layers of thin-film solar cells. For instance, it is well-known that the band gap of $\mathrm{CuInS}_{2} \mathrm{NCs}$ is about 1.5 $\mathrm{eV}$, which matches well with the solar spectrum. Meanwhile, $\mathrm{CuInS}_{2} \mathrm{NCs}$ have relatively low toxicity and they are more environmentally friendly than II-VI semiconductor nanoparticles. Both the high absorption coefficients and low toxicity make them prime candidates for the absorbing materials of next-generation solar cells. A statistical table on the efficiencies of nanocrystal-based solar cells is included below (Table 4).

Wang and co-workers [20] reported a solvothermal approach to compound $\mathrm{CuInS}_{2}$ quantum dots, and a solar cell was constructed using a combination of $\mathrm{CuInS}_{2}$ quantum dots and poly(2-methoxy-5-(2-ethylhexyloxy)-1,4-phenylene vinylene) (MEH-PPV). Firstly, a PEDOT:PSS layer was spin-coated on an ITO substrate. Then, a mixture of MEH-PPV/CuInS2-QDs layer as an absorbing material was spin-coated from chlorobenzene
Table 4

Overview of the efficiency of nanocrystal-based solar cells.

\begin{tabular}{|c|c|c|c|c|c|}
\hline Material & PCE (\%) & $V_{o c} /(\mathrm{mV})$ & $J_{s c} /\left(\mathrm{mA} \mathrm{cm}^{-2}\right)$ & $F F(\%)$ & Ref. \\
\hline \multirow[t]{6}{*}{$\mathrm{CuInSe}_{2}$} & 2.82 & 280 & 25.8 & 39 & [11] \\
\hline & 3.1 & 410 & 16.3 & 46 & [13] \\
\hline & 0.24 & 320 & 3.2 & 25 & [15] \\
\hline & 0.1 & 182 & 1.85 & 29.7 & [102] \\
\hline & 1.93 & 476 & 8.3 & 48.8 & [103] \\
\hline & 8.2 & 440 & 33.7 & 55 & [53] \\
\hline \multirow[t]{2}{*}{$\mathrm{CuInS}_{2}$} & 0.74 & 190 & 13.59 & 28.6 & [10] \\
\hline & 4.45 & 380 & 30.1 & 47.6 & [12] \\
\hline $\mathrm{CuInS}_{2}: \mathrm{Zn}$ & 7.53 & 594 & 23.7 & 50 & [153] \\
\hline \multirow[t]{2}{*}{ CuInGaS } & 12 & 630 & 28.8 & 65.7 & [14] \\
\hline & 5.5 & 460 & 23.7 & 51 & [106] \\
\hline \multirow[t]{4}{*}{$\mathrm{Cu}_{2} \mathrm{ZnSnS}_{4}$} & 0.23 & 321 & 1.95 & 37 & [107] \\
\hline & 0.8 & 210 & 11.5 & 33 & [18] \\
\hline & 7.23 & 430 & 31.2 & 53.9 & [108] \\
\hline & 1.94 & 484 & 8.91 & 45.1 & [109] \\
\hline \multirow[t]{2}{*}{$\mathrm{Cu}_{2} \mathrm{ZnSn}(\mathrm{S}, \mathrm{Se})_{4}$} & 16.9 & 690 & 23 & 11.8 & [152] \\
\hline & 25.58 & 990 & 29.1 & - & [154] \\
\hline
\end{tabular}

PCE: power conversion efficiency, $V_{o c}$ : open circuit voltage, $J_{s c}$ : short circuit current, $F F$ : fill factor.

over the PEDOT:PSS layer. Secondly, an extra layer of CuInS 2 quantum dots dispersed in ethanol was spin-coated over the photoactive layer as a hole blocking layer. Finally, a LiF and Al film was deposited onto the $\mathrm{CuInS}_{2}$ layer by thermal evaporation (Fig. 7(a)). Clearly, the device has a wide spectral response from 300 to $900 \mathrm{~nm}$ (Fig. 7(b)).

The usage of NCs in solar cells shows a baseline performance; therefore, it still requires higher efficiency in practical devices. There are many methods to improve the power conversion efficiency (PCE) of NCs-based device, including using shorter chain capping ligands, various chemicals or thermal treatments to increase their conductivity, and by low-temperature synthesis [110-115].

\section{2. $\quad$ Light-emitting diodes (LEDS)}

Phosphor-converted white light-emitting diodes
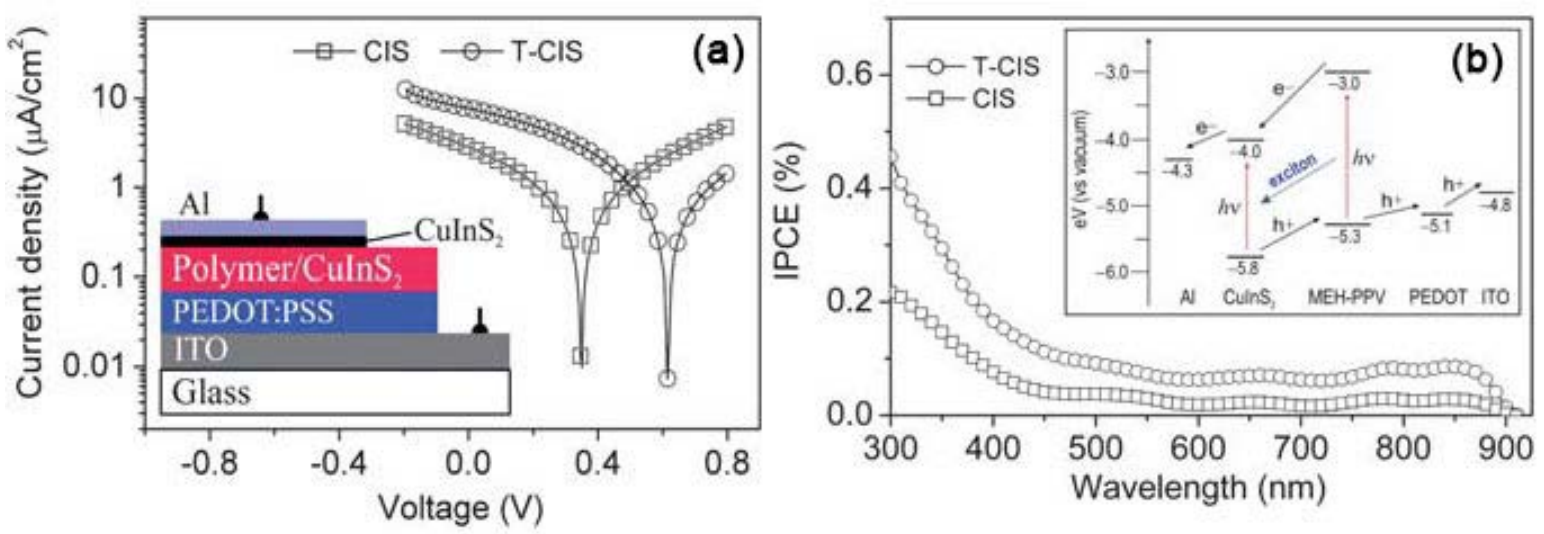

Fig. 7. (a) $J-V$ curves of the solar cells based on the blends of MEH-PPV and CuInS 2 QDs at blends ratio $(\mathrm{R})=1 / 1$ under monochromatic illumination of $15.85 \mathrm{~mW} \mathrm{~cm}^{-2}$ at $470 \mathrm{~nm}$. The inset shows the device architecture. CIS and T-CIS represent the as-synthesized and TBP-treated CuInS 2 QDs, respectively. (b) IPCE spectra of the solar cells based on the blends of MEH-PPV and CuInS 2 QDs at R = 1/1, where CIS and T-CIS have the same meanings as those in (a). The inset schematically illustrates the energy level diagram for the devices based on MEH-PPV and CuInS 2 QDs, showing charge transfer of electrons to $\mathrm{CuInS}_{2}$ and holes to MEHPPV, in which exciton transfer, as indicated by the blue dotted arrows, represents a possible process for the energy loss of polymer excitons [20]. 

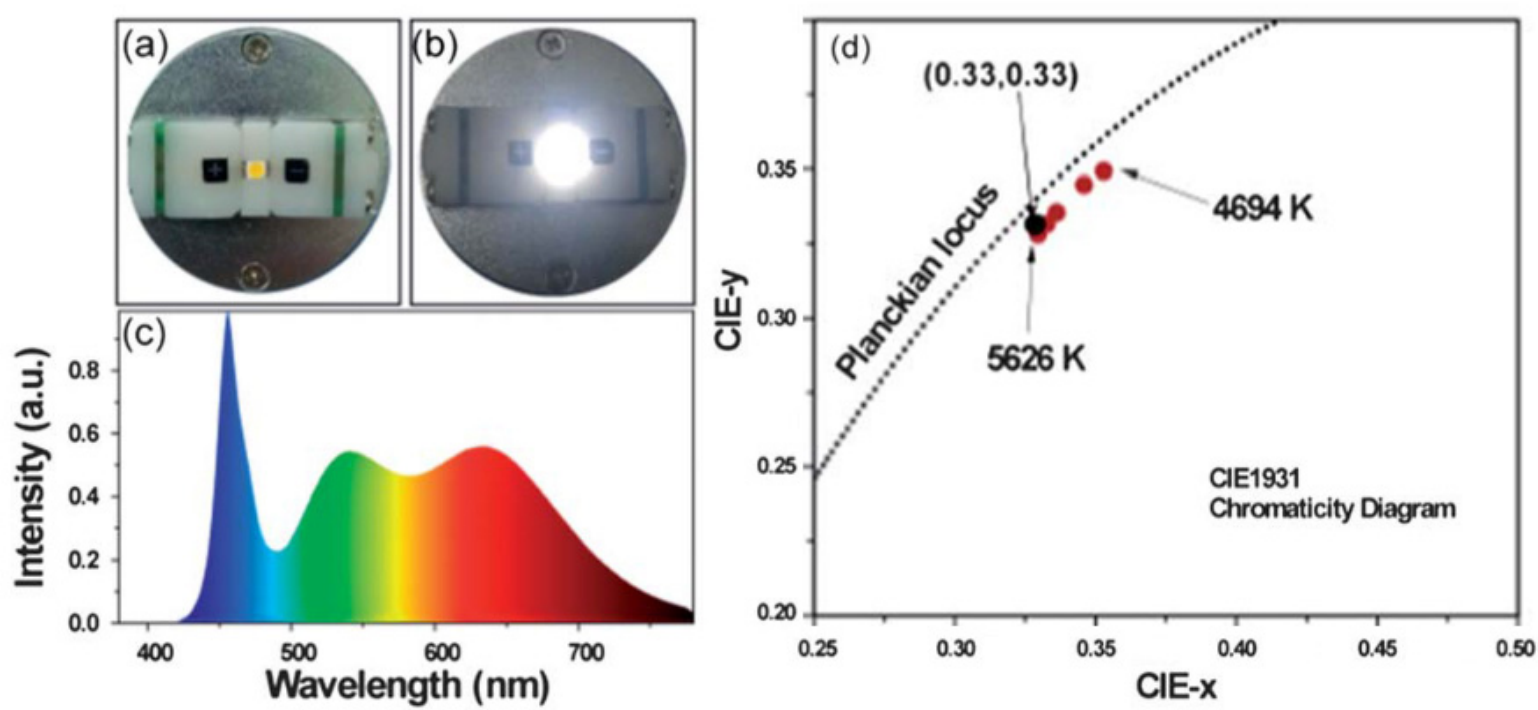

Fig. 8. Photographs of (a) the as-fabricated surface mounted device (SMD) type WLED from two different emissive CuInS ${ }_{2}$-based NCs and (b) the WLED operated at a forward bias current of $20 \mathrm{~mA}$. (c) EL spectrum of the device operated at $20 \mathrm{~mA}$. (d) CIE color coordinates of the devices based on green and red emissive CuInS 2 -based NCs at weight ratios of 50:1-25:1 [118].

(pc-WLEDs), formed by combining blue-emitting chips with down-converting phosphors, are potential candidates to replace incandescent lamps [116]. Owing to the inefficient properties and serious supply issues of traditional rare-earth phosphors, researchers used quantum dots (QDs) as an ideal replacement for traditional phosphors. The WLEDs based on NCs (nc-WLEDs) are low-cost, have high efficiency, and render high color [117]. Zhong et al. [118] fabricated WLEDs with luminous efficiency, a high-color rendering index (CRI), and tunable color temperature; they are based on $\mathrm{CuInS}_{2}$ NCs. The obtained nc-WLEDs devices exhibited a luminous efficiency of $70 \mathrm{~lm} \mathrm{~W}^{-1}$, CRI of 95, and a tunable color temperature of 4600-5600 K (Fig. 8). The result shows an obvious improvement over previously fabricated nc-WLEDs [119]. This work indicates that $\mathrm{CuInS}_{2}$ NCs are promising candidates for commercial applications. Peng et al. [120] reported a non-injection, low-cost, and one-pot approach for the synthesis of CuInZnS NCs. When the
NCs are combined with a commercial blue LED chip, the color converter gave a high color rendering index of about 90 and commission Internationale de l'eclairage (CIE) color coordinates of $(0.332,0.321)$. These results suggest that this kind of NCs, which are cadmium-free, thermally stable, and single-phase, have potential applications in WLEDs. A statistical table on the properties of I-III-VI NC-based WLEDs is included below (Table 5).

The excellent optical properties of I-III-VI semiconductor QDs make them ideal candidates for quantum dot-based LEDs (QD-LEDs), which are new-generation display technologies. QD-LEDs possess the advantages of low cost, superior color tunability, large area, and compatibility with various substrates. Zhong et al. [23] fabricated QD-LEDs with CuInS 2 NCs. The structure of a typical ITO/hole transport layer (HTL)/NCs/electron transport layer (ETL)/Ca/Al was employed to fabricate CuInS2-based QD-LEDs.

Table 5

Summary of properties of I-III-VI NC-based WLEDs.

\begin{tabular}{|c|c|c|c|c|c|}
\hline Color-converting materials & Luminous efficiency $(\mathrm{lm} / \mathrm{W})$ & Applied current (mA) & CCT $(\mathrm{K})$ & CRI & Ref. \\
\hline \multirow[t]{2}{*}{ green CIGS/CIGS-ZnS/ZnS QDs + red InP/ZnS QDs } & 34.7 & $20-80$ & 5322 & 94 & [46] \\
\hline & & & 3691 & 92 & \\
\hline green $(\mathrm{CdSe})_{x}(\mathrm{ZnS})_{1-x}+\operatorname{red}\left(\mathrm{CuInS}_{2}\right)_{x}(\mathrm{ZnS})_{1-x}(0<x<1)$ & 82 & 100 & 2307 & 76 & [75] \\
\hline yellow CIZS/ZnS QDs & & 20 & 4793 & 80 & [105] \\
\hline yellow YAG:Ce + red CuInS NCs & 91.4 & 20 & 5420 & 81.9 & [119] \\
\hline \multirow[t]{3}{*}{ Mn-doped Zn-Cu-In-S } & & 20 & 5328 & 87 & {$[120]$} \\
\hline & & 40 & 5680 & 90 & \\
\hline & & 60 & 6939 & 89 & \\
\hline bicolor green and orange CIS/ZnS:Mn/ZnS QD & 61 & 20 & $4000-6000$ & 83 & [121] \\
\hline yellow $\mathrm{AgIn}_{5} \mathrm{~S}_{8}-\mathrm{ZnS} \mathrm{NCs}$ & 53 & 60 & 3700 & 44 & {$[122]$} \\
\hline $\mathrm{CIS} / \mathrm{ZnS}$ & 63.4 & $5-100$ & $4447-5380$ & $72-75$ & [123] \\
\hline green Zn-Ag-In-S and red Zn-Cu-In-S QDs & 31.2 & 29 & 3500 & 97 & [124] \\
\hline green $\mathrm{InP} / \mathrm{ZnS}+$ red CIS/ZnS & 45.5 & 20 & 3803 & 90 & {$[125]$} \\
\hline yellow YAG:Ce nanoparticles + red CIS/ZnS QDs & 21.1 & 1200 & 3934 & 84.6 & {$[126]$} \\
\hline
\end{tabular}

CCT: correlated color temperature, CRI: color rendering index. 

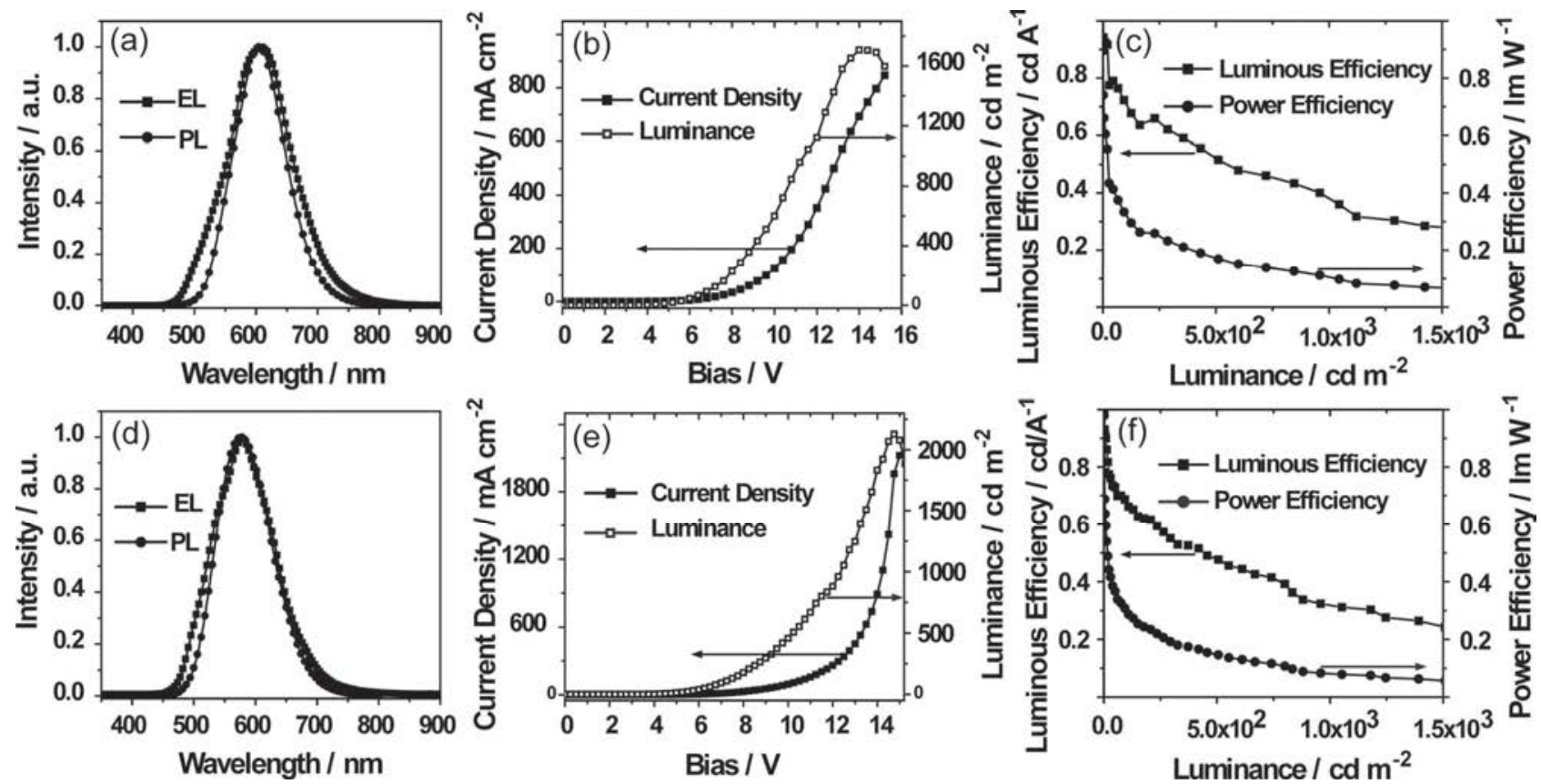

Fig. 9. (a, d) PL spectra and corresponding EL of two selected CuInS 2 -based core/shell samples with PL emission peak at 606 and 577 nm. (b, e) Current density and luminance of the devices with red and yellow emission as a function of applied bias. (c, f) Current efficiency and power efficiency of red and yellow devices as a function of current density [23].

Poly[ $N, N$-bis(4-butylphenyl)- $N, N$-bis(phenyl)benzidine] (PolyTPD) and tris-(8-hydroxyquinoline) aluminium ( $\left.\mathrm{Alq}_{3}\right)$ were chosen as the HTL and ETL, respectively. The luminescent layer consisted of $\mathrm{CuInS}_{2} \mathrm{NCs}$. The similarities between the electroluminescence (EL) and PL spectra indicate that the device emission was due to NCs (Fig. 9(a) and (d)). When the bias voltage was $14 \mathrm{~V}$, the red devices reached a maximum luminance of $1700 \mathrm{~cd} \mathrm{~m}^{-2}$. When the bias voltage was $15 \mathrm{~V}$, the yellow devices reached a maximum luminance of $2100 \mathrm{~cd} \mathrm{~m}^{-2}$ (Fig. 9(b) and (e)). A statistical table on the properties of I-III-VI NC-based EL devices is included below (Table 6).

\subsection{Bioimaging}

Semiconductor NCs in aqueous media are highly fluorescent and photostable and these characteristics make them excellent materials for bioimaging [127-131]. They meet the essential requirements for application in the human body: small hydrodynamic diameters (smaller than $10 \mathrm{~nm}$ ) can promote $\mathrm{NC}$ elimination through renal clearance, light scattering, and absorption in biological media that can be avoided by NIR [18].
Their low toxicity further makes I-III-VI NCs extremely promising for clinical research. Liu and co-workers prepared $\mathrm{CuInS}_{2} / \mathrm{ZnS}$ and $\mathrm{AgInS} \mathrm{S}_{2} / \mathrm{ZnS}$ NCs, which are water dispersible, and demonstrated high biocompatibility for both deep tissue penetration and tumor targeting. A dosage of $110 \mathrm{mg} \mathrm{kg}^{-1}$ of AgInS $2 / Z n S$ QD-micelle formulation ( $400 \mathrm{~mL}$ ) was injected into Kunming mice through the tail vein. Images were taken at the zero hour and two hours after injection. As shown in Fig. 10(A), the signal from the NIR QDs could be clearly observed in the tail right after the injection. Two hours later, the luminescence was transferred into the tumor matrix through the enhanced permeability and retention (EPR) effect. In another study, $\mathrm{CuInS}_{2} / \mathrm{ZnS}$ QDs were injected into Kunming mice through the enterocoelia. The high luminescence signals can be observed in Fig. 10(B). Although the luminescence generates from deep under the skin, the signal can be easily differentiated from the background auto-fluorescence signal [25]. Therefore, these experiments on Kunming mice demonstrated that ternary core-shell structure quantum dots, such as CuInS $2 / \mathrm{ZnS}$ and $\mathrm{AgInS}_{2} / \mathrm{ZnS}$, could serve as an excellent NIR contrast agents for in vivo bioimaging.

Table 6

Summary of the properties of I-III-VI NC-based EL devices.

\begin{tabular}{|c|c|c|c|c|c|c|}
\hline Material & Device structure & Wavelength (nm) & Luminance $\left(\mathrm{cd} \mathrm{m}^{-2}\right)$ & Current efficiency $\left(\mathrm{cd} \mathrm{A}^{-1}\right)$ & EQE (\%) & Ref. \\
\hline $\mathrm{CuInS}_{2} / \mathrm{ZnS}$ & ITO/PEDOT:PSS/QDs/ZnO/Ga/Al & $500-800$ & 2100 & 0.92 & - & {$[23]$} \\
\hline $\mathrm{CuInS}_{2} / \mathrm{ZnS}$ & TO/ZnO/QDs/CBP/TCTA/MoO3/Al & 560 & 8375 & 9.43 & 3.22 & [146] \\
\hline $\mathrm{CuInS}_{2} / \mathrm{ZnS}$ & ITO/PEDOT:PSS/TFB/QDs/ZnO/Al & $577-602$ & 8464 & 18.2 & 7.3 & [147] \\
\hline $\mathrm{CuInS}_{2} / \mathrm{ZnS}$ & ITO/PEDOT:PSS/Poly-TPD/QDs/ZnO:Mg/Al & $620-730$ & 175 & 0.48 & 3.36 & [148] \\
\hline Ag-In-Zn-S/ZnS & ITO/PEDOT:PSS/PVK/QDs/ZnO/Al & $525-570$ & 698 & 0.36 & 0.49 & [149] \\
\hline Cu-In-Zn-S/ZnS & ITO/PEDOT:PSS/TFB/TFB:QDs/ZnO/Al & white light & 1500 & 0.13 & - & [150] \\
\hline ZnCuInS/ZnS & ITO/PEDOT:PSS/Ploy-TPD/QDs/Al & white light & 450 & - & 0.033 & [151] \\
\hline
\end{tabular}

EQE: external quantum efficiency. 


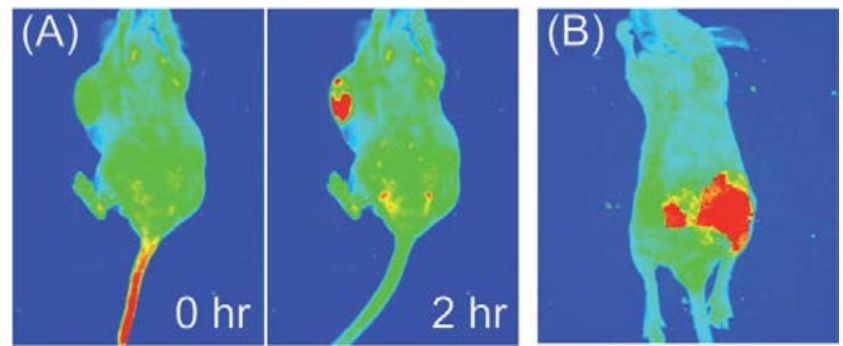

Fig. 10. Luminescence images of mice treated with $\mathrm{AgInS}_{2} / \mathrm{ZnS}$ and $\mathrm{CuInS}_{2} / \mathrm{ZnS}$ QDs through tail-vein injection (A) and intra-abdominal injection (B) [25].

Chang and co-workers [132] attached intrinsically radioactive ${ }^{64} \mathrm{Cu}$ onto $\mathrm{CuInS} 2 / \mathrm{ZnS}$ QDs. This work not only exploited their positron emission tomography (PET) functionality, but also resulted in self-illuminating QDs, with no need for an external light source. $\left[{ }^{64} \mathrm{Cu}\right] \mathrm{CIS} / \mathrm{ZnS}$ QDs exhibit great potential in PET/self-illuminating luminescence imaging. Liang et al. [133] applied $\mathrm{CuInS}_{2} / \mathrm{ZnS}$ (ZCIS) NCs to theranostic nanomedicines (NMs); these all-in-one NMs combined intrinsic imaging and therapeutic capabilities within a well-defined nanostructure. Benefiting from the intrinsic fluorescence/multispectral optical tomography (MSOT) imaging ability of ZCIS QDs, their size-dependent distribution profiles can be obviously visualized at tumor sites in vivo. The researchers used ZCIS QDs for
MSOT imaging and synergistic photodynamic therapy (PDT)/photothermal therapy (PTT). They encapsulated the initially hydrophobic ZCIS QDs into lipid-PEG (DSPE-PEG) micelles to obtain ZCIS NMs. By varying the amount of DSPE-PEG, ZCIS NMs with hydrodynamic diameters (HDs) of 25.3 and 82 nm were prepared and designated as ZCIS NMs-25 and ZCIS NMs-80, respectively. The two NMs were injected into two mice separately. Then the mice with tumors were subjected to NIR fluorescence and MSOT imaging and the contrast at the tumor site was markedly enhanced from $4 \mathrm{~h}$ post-injection. The PA signal intensity in the tumor was enhanced by over $300 \%$ after $24 \mathrm{~h}$ post-injection of ZCIS NMs-25, while the photoacoustic (PA) signal intensity in the tumor was enhanced by less than $200 \%$ in the case of ZCIS NMs-80 (Fig. 11(a)); the PA signal was markedly visible even up to $48 \mathrm{~h}$ post-injection compared to the case where mice were injected with ZCIS NMs-80, indicating a longer tumor retention time (Fig. 11(b)-(d)). This result indicated the efficient passive targeting and MSOT imaging abilities of ZCIS NMs in vivo.

\subsection{Photocatalysis for $\mathrm{H}_{2}$ evolution}

Along with societal development, environmental and energy issues have gained great importance. As a means to effectively generate energy and degrade poisonous and harmful sub- (a) ZCIS NMs-25

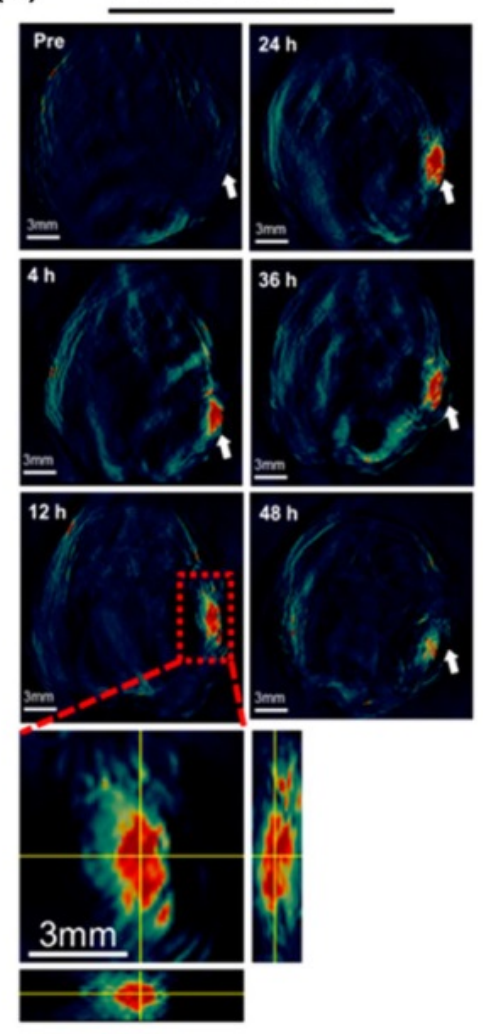

ZCIS NMs-80

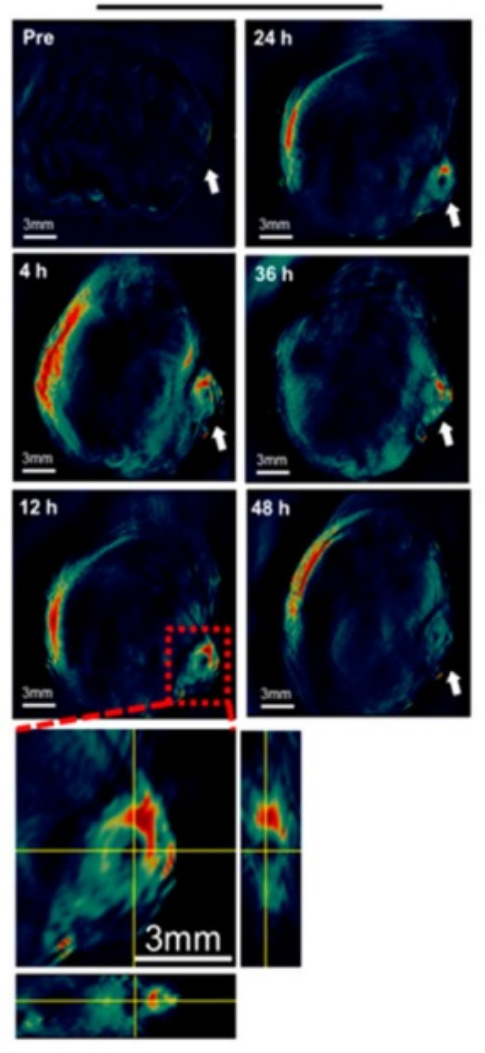

(b)

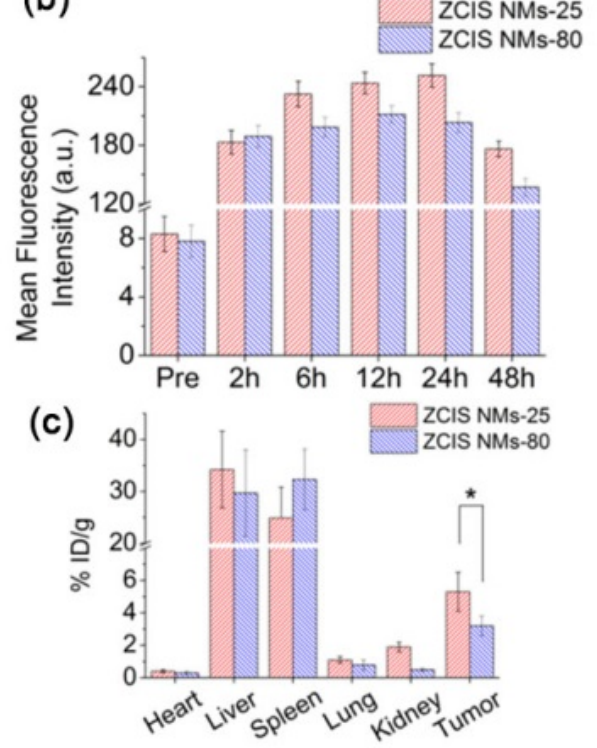

(d)

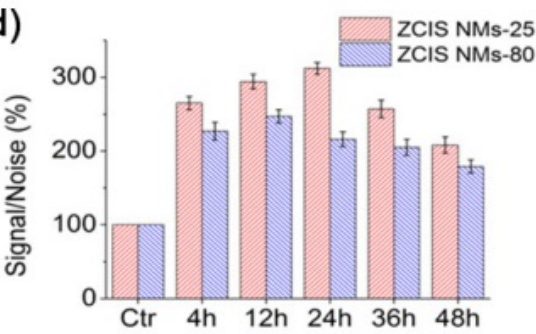

Fig. 11. In vivo fluorescence and MSOT imaging. (a) In vivo MSOT images of tumors (arrows) in mice taken at different times after the intravenous injection of ZCIS NMs-25 and ZCIS NMs-80. Enlarged orthogonal views of the tumor region are also presented; (b) Average fluorescence intensities of the tumor areas over $48 \mathrm{~h}$ after injection; (c) Biodistribution of ZCIS NMs-25 and ZCIS NMs-80 in the major organs of 4 T1 tumor-bearing mice at $48 \mathrm{~h}$ post-injection and (d) MSOT signal enhancement in the tumor at different time points post-injection [133]. 
stances, photocatalysis has gained a lot of attention [157]. II-VI NCs have been widely studied for a long time $[158,159]$, but the presence of toxic elements restricts their further applications. Hydrogen is a potential green fuel with high energy and hence, $\mathrm{H}_{2}$ evolution is a research hotspot. Water splitting is one of the most efficient methods to generate $\mathrm{H}_{2}$ [134]. A ZnS photocatalyst with a wide band gap and $\mathrm{AgInS}_{2}$ with a narrow band gap could generate a solid solution of $(\operatorname{AgIn})_{x} \mathrm{Zn}_{2}(1-x) \mathrm{S}_{2}$, whose photocatalytic activities and photophysical properties depend on the composition. With the help of Pt cocatalysts, the photocatalysts can achieve high photocatalytic activities. Pt(3 wt\%)-loaded (AgIn) $0.22 \mathrm{Zn}_{1.56} \mathrm{~S}_{2}\left(\sim \mathrm{AgInZn}_{7} \mathrm{~S}_{9}\right)$ with a $2.3 \mathrm{eV}$ band gap showed the highest activity for $\mathrm{H}_{2}$ evolution. The visible-light response of the solid solution is due to the contributions of Ag and In to the valence and conduction bands, respectively [135]. In this study, $\mathrm{Cu}^{+}$was reported to form a stable valence band and enhance visible-light response. Introduction of $\mathrm{Cu}^{+}$into photocatalysts can yield a relatively high activity for $\mathrm{H}_{2}$ evolution without any cocatalysts [136-138]. Tang and co-workers [139] studied a facile method for the synthesis of CuInZnS nanoporous spheres at room temperature. The morphology of the nanoporous spheres can impede particle aggregation and retain high surface area during photocatalytic applications. $\mathrm{H}_{2}$ evolution from the obtained nanospheres under visible light was as high as $2.35 \mathrm{mmol} \mathrm{h}^{-1} \mathrm{~g}^{-1}$ from water without any other co-catalysts when the ratio of $\mathrm{Cu} / \mathrm{Zn}$ was 0.04 (Fig. 12), which is a considerably high value for the CIZS system. However, the excessively fast recombination of the surface electron-hole pairs limited its photocatalysis application. How to restrain the surface recombination rate becomes another urgent research question. Water-splitting photoelectrode devices, which require an external bias in order to drive water electrolysis and control the recombination of photogenic charge carriers, are efficient for $\mathrm{H}_{2}$ evolution [140]. Dong et al. [141] used $\mathrm{ZnIn}_{0.25} \mathrm{Cu}_{0.02} \mathrm{~S}_{1.395}$ to decorate the surface of a ZnO@ $\mathrm{TiO}_{2}$ nanorod array (NRA) and applied it to photoelectrochemical (PEC) water splitting (Fig. 13); the current density

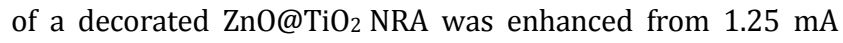
$\mathrm{cm}^{-2}$ to $7.28 \mathrm{~mA} \mathrm{~cm}-2$. They further used the decorated

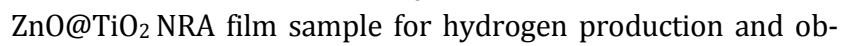
tained about $12 \mu \mathrm{mol}$ hydrogen gas during $4 \mathrm{~h}$ of reaction. Liu and co-workers [142] generated 2D Cu-In-Zn-S nanosheets
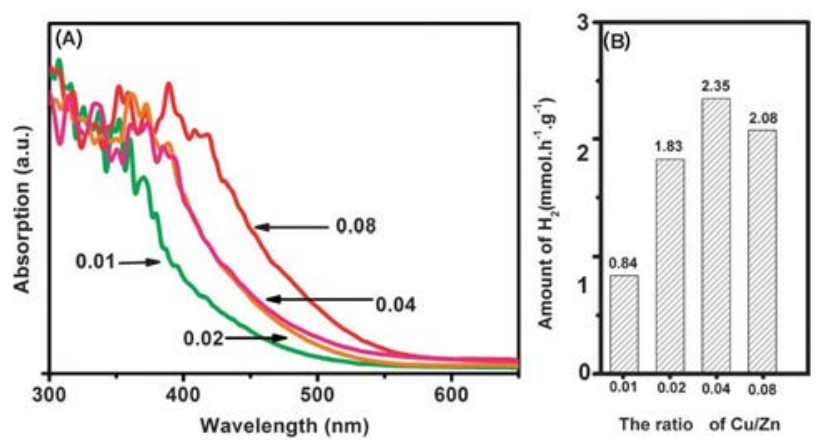

Fig. 12. (A) UV-Vis absorption spectra of the CIZS spheres with different amounts of $\mathrm{Cu}$. (B) Hydrogen evolution from an aqueous solution containing $1.2 \mathrm{~mol} \mathrm{~L}^{-1} \mathrm{Na}_{2} \mathrm{SO}_{3}$ and $0.7 \mathrm{~mol} \mathrm{~L}^{-1} \mathrm{Na}_{2} \mathrm{~S}$ and catalyzed by CIZS spheres with different amounts of doped $\mathrm{Cu}$ [139].

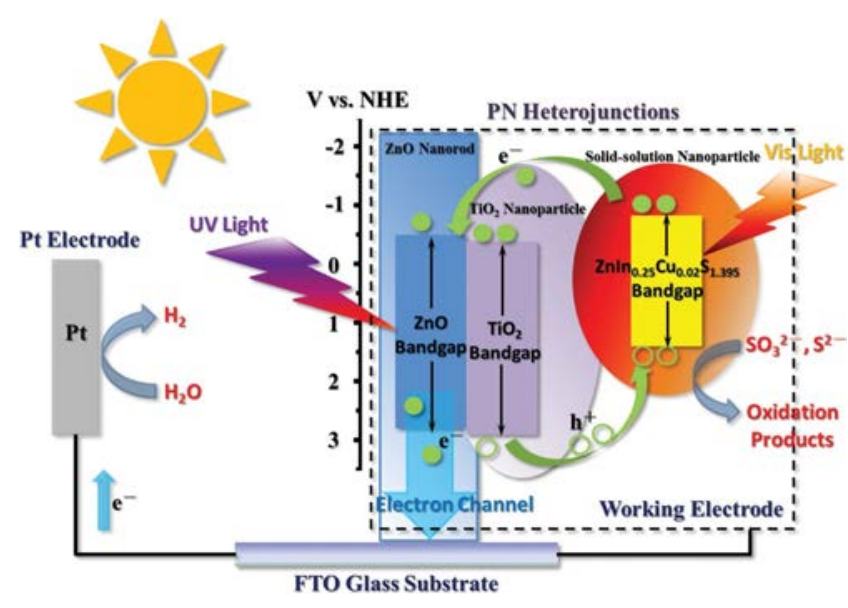

Fig. 13. Photoinduced electron separation and transportation process in the $\mathrm{ZnO} @ \mathrm{TiO}_{2}$ nanorod array film loaded with a $\mathrm{ZnIn}_{0.25} \mathrm{Cu}_{0.02} \mathrm{~S}_{1.395}$ solid solution [141].

based on a $\mathrm{ZnInS}_{2}$ nanosheets template. This group applied CIZS nanosheets to PEC water splitting for the first time. A novel $\mathrm{ZnS}$ shell/2D Cu-Zn-In-S nanosheets/1D $\mathrm{TiO}_{2}$ nanorods heterostructure was fabricated and the $\mathrm{ZnS}$ shell was capped by successive ionic layer adsorption and reaction. The as-prepared samples were used as the working electrodes, whose active area was $0.16-0.20 \mathrm{~cm}^{2}$, a Pt mesh as the counter electrode, and a saturated $\mathrm{Ag} / \mathrm{AgCl}$ electrode as the reference. According to the PEC experimental results, photocurrent density was enhanced from $0.34 \mathrm{~mA} \mathrm{~cm}^{-2}$ for pristine $\mathrm{TiO}_{2}$ to $0.81 \mathrm{~mA} \mathrm{~cm}^{-2}$ for the heterojunction at $0.8 \mathrm{~V}$ versus a reversible hydrogen electrode.

\section{Conclusions and outlook}

Years of development, various studies, and practical applications indicate that semiconductor NCs can play an important role in many fields, especially in solar cells, light-emitting diodes, bioimaging, and photocatalysis. When semiconductor NCs were referred to previously, it usually meant II-VI semiconductor nanoparticles. However, a large number of conventional II-VI semiconductor nanoparticles are toxic, which limited their development. Thus, I-III-VI semiconductors NCs are attracting much interest from scientists owing to their low toxicity and tunable emission wavelengths ranging from the visible region to the NIR. However, there are still some limitations that need to be focused on.

(1) In order to have a better control over the composition, morphology, and luminescence yields, scientists should spend more effort on investigating the mechanisms involved in the NC synthesis process and their fundamental electronic properties. The size, composition, crystal structure, and inner and surface defects should be more precisely controlled.

(2) As for the applications, high-efficiency solar cells are expected. Methods for improving PV efficiency include using shorter chain capping ligands, using various chemicals or thermal treatments to increase their conductivity, and using low-temperature synthesis processes. Applications relying on the emission properties, such as light-emitting diodes and bi- 
oimaging, will benefit from a reduction in the photoluminescence line width.

(3) Although I-III-VI semiconductor NCs have low toxicity and are more environmentally friendly than binary NCs, potential risks still exist and should be further investigated and evaluated.

\section{References}

[1] F. J. Fan, L. Wu, S. H. Yu, Energy Environ. Sci., 2014, 7, 190-208.

[2] T. Torimoto, T. Adachi, K. Okazaki, M. Sakuraoka, T. Shibayama, B. Ohtani, A. Kudo, S. Kuwabata, J. Am. Chem. Soc., 2007, 129, 12388-12389.

[3] C. B. Murrag, D. B. Norris, M. G. Bawendi, J. Am. Chem. Soc., 1993, $115,8706-8715$.

[4] X. S. Tang, W. B. A. Ho, J. M. Xue, J. Phys. Chem. C, 2012, 116, 9769-9773.

[5] H. Yang, L. A. Jauregui, G. Zhang, Y. P. Chen, Y. Wu, Nano Lett., 2012, 12, 540-545.

[6] S. G. Kwon, T. Hyeon, Small, 2011, 7, 2685-2702.

[7] S. L. Castro, S. G. Bailey, R. P. Raffaelle, K. K. Banger, A. F. Hepp, Chem. Mater., 2003, 15, 3142-3147.

[8] A. D. P Leach, J. E. Macdonald, J. Phys. Chem. Lett., 2016, 7, 572-583.

[9] Z. H. Gong, Q. Q. Han , J. Li, L. P. Hou, A. Bukhtiar, S. Yang, B. S. Zou, J. Alloys Compd., 2016, 663, 617-623.

[10] W. C. Huang, C. H. Tseng, S. H. Chang, H. Y. Tuan, C. C. Chiang, L. M. Lyu, M. H. Huang, Langmuir, 2012, 28, 8496-8501.

[11] Q. J. Guo, S. J. Kim, M. Kar, W. N. Shafarman, R. W. Birkmire, E. A. Stach, R. Agrawal, H. W. Hillhouse, Nano lett., 2008, 8, 2982-2987.

[12] G. M. Ford, Q. J. Guo, R. Agrawal, H. W. Hillhouse, Thin Solid Films, 2011, 520, 523-528.

[13] V. A. Akhavan, M. G. Panthani, B. W. Goodfellow, D. K. Reid, B. A. Korgel, Opt. Express, 2010, 18, A411-A420.

[14] Q. J. Guo, G. M. Ford, R. Agrawal, H. W. Hillhouse, Prog. Photovolta- ics, 2013, 21, 64-71.

[15] M. G. Panthani, V. Akhavan, B. Goodfellow, J. P. Schmidtke, L. Dunn, A.Dodabalapur, P. F. Barbara, B. A. Korge, J. Am. Chem. Soc., 2008, 130, 16770-16777.

[16] D. L. Ferreira, J. C. L. Sousa, R. N. Maronesi, J. Bettini, M. A. Schiavon, A. V. N. C. Teixeira, A. G. Silva, J. Chem. Phys., 2017, 147, 154102/1-154102/9.

[17] A. H. Khan, U. Thupakula, A. Dalui, S.Maji, A. Debangshi, S. Acharya, J. Phys. Chem. C, 2013, 117, 7934-7939.

[18] Q. J. Guo, H. W. Hillhouse, R. Agrawal, J. Am. Chem. Soc., 2009, 131, 11672-11673.

[19] S. Y. Liu, X. G. Su, RSC Adv., 2014, 4, 43415-43428.

[20] W. J. Yue, S. K. Han, R. X. Peng, W. Shen, H. W. Geng, F. Wu, S. W. Tao, M. T. Wang, J. Mater. Chem., 2010, 20, 7570-7578.

[21] C. H. M. Chuang, P. R. Brown, V. Bulović, M. G. Bawendi, Nat. Mater., 2014, 13, 796-801.

[22] H. Z. Zhong, Y. Zhou, M. F. Ye, Y. J. He, J. P. Ye, C. He, C. H. Yang, Y. F. Li, Chem. Mater., 2008, 20, 6434-6443.

[23] B. K. Chen, H. Z. Zhong, W. Q. Zhang, Z. A. Tan, Y. F. Li, C. R. Yu, T. Y. Zhai, Y. Bando, S. Y. Yang, B. S. Zou, Adv. Funct. Mater., 2012, 22, 2081-2088.

[24] D. Aldakov, A. Lefrançois, P. Reiss, J. Mater. Chem. C, 2013, 1, 3756-3776.

[25] L. W. Liu, R. Hu, W. C. Law, I. Roy, J. Zhu, L. Ye, S. Y. Hu, X. H. Zhang, K. T. Yong, Analyst, 2013, 138, 6144-6153.

[26] X. S. Tang, W. I. Cheng, E. S. G. Choo, J. M. Xue, Chem. Commun., 2011, 47, 5217-5219.

[27] L. Shi, C. J. Pei, Q. Li, Nanoscale, 2010, 2, 2126-2130.

[28] Q. H. Zhang, Y. Tian, C. F. Wang, S. Chen, RSC Adv., 2016, 6, 47616-47622.

[29] W. W. Xiong, G. H. Yang, X. C. Wu, J. J. Zhu, ACS Appl. Mater. interfaces, 2013, 5, 8210-8216.

[30] X. T. Lu, Z. B. Zhuang, Q. Peng; Y. D. Li, CrystEngComm, 2011, 13, 4039-4045.

[31] L. Shi, P. Q. Yin, L. B. Wang, Y. T. Qian, CrystEngComm, 2012, 14, 7217-7221.

\section{Graphical Abstract}

Chin. J. Catal., 2018, 39: 590-605 doi: 10.1016/S1872-2067(18)63052-9

I-III-VI chalcogenide semiconductor nanocrystals: Synthesis, properties, and applications

Shiqi Li, Xiaosheng Tang* Z Zhigang Zang, Yao Yao, Zhiqiang Yao, Haizheng Zhong, Bingkun Chen

Chongqing University;

Chengdu University of Information Technology;

Zhengzhou University; Beijing Institute of Technology

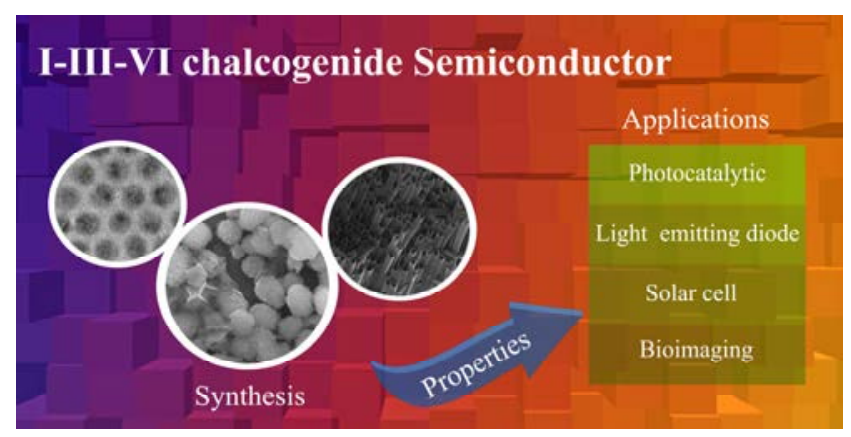

The synthesis methods, properties, and applications of I-III-VI chalcogenide semiconductor nanocrystals are reviewed in detail. The challenges and future outlook of this domain are also discussed in this review. 
[32] J. Yang, C. X. Bao, J. Y. Zhang, T. Yu, H. Huang, Y. I. Wei, H. Gao, G. Fu, J. G. Liu, Z. G. Zou, Chem. Commun., 2013, 49, 2028-2030.

[33] Q. Li, C. Zou, L. I. Zhai, L. J. Zhang, Y. Yang, X. A. Chen, S. M. Huang, CrystEngComm, 2013, 15, 1806-1813.

[34] J. J. He, W. H. Zhou, M. Li, Z. L. Hou, Y. F. Du, S. X. Wu, Mater. Lett., 2012, 66, 96-98.

[35] H. Nakamura, W. Kato, M. Uehara, K. Nose, T. Omata, S. Otsuka-Yao-Matsuo, M. Miyazaki, H. Maeda, Chem. Mater., 2006, 18, 3330-3335.

[36] H. Z. Zhong, S. S. Lo, T. Mirkovic, Y. C. Li, Y. Q. Ding, Y. F. Li, G. D. Scholes, ACS Nano, 2010, 4, 5253-5262.

[37] S. D. Perera, H. T. Zhang, X. Y. Ding, A. Nelson, R. D. Robinson, J. Mater. Chem. C, 2015, 3, 1044-1055.

[38] T. L. Li, Y. L. Lee, H. Teng, J. Mater. Chem., 2011, 21, 5089-5098.

[39] S. Y. Liu, H. Zhang, Y. Qiao, X. G. Su, Rsc Adv., 2012, 2, 819-825.

[40] X. S. Tang, W. Wei, C. C. C. Khng, Z. G. Zang, M. Deng, T. Zhu, J. M. Xue, Nanotechnology, 2014, 25, 485702/1-485702/6.

[41] J. Park, S. W. Kim, J. Mater. Chem., 2011, 21, 3745-3750.

[42] M. Y. Chiang, S. H. Chang, C. Y. Chen, F. W. Yuan, H. Y. Tuan, J. Phys. Chem. C, 2011, 115, 1592-1599.

[43] A. Zhang, Q. Ma, M. Lu, G. W. Yu, Y. Y. Zhou, Z. F. Qiu, Cryst. Growth \& Des., 2008, 8, 2402-2405.

[44] C. L. Yu, C. Y. Jimmy, H. R. Wen, C. X. Zhang, Mater. Lett., 2009, 63, 1984-1986.

[45] C. Sun, J. S. Gardner, G. Long, C. Bajracharya, A. Thurber, A. Punnoose, R. G. Rodriguez, J. J. Pak, Chem. Mater., 2010, 22, 2699-2701.

[46] J. H. Kim, H. Yang, Nanotechnology, 2014, 25, 225601/1-225601/7.

[47] A. D. P. Leach, L. G. Mast, E. A. Hernandez-Pagan, J. E. Macdonald, J. Mater. Chem. C, 2015, 3, 3258-3265.

[48] W. H. Zhou, J. Jiao, Y. Zhao, X. Y. Cheng, D. X. Kou, Z. J. Zhou, S. X. Wu, RSC Adv., 2014, 4, 7617-7622.

[49] F. C. Gong, S. Q. Tian, B. S. Liu, D. H. Xiong, X. J. Zhao, RSC Adv., 2014, 4, 36875-36881.

[50] Q. Li, L. L. Zhai, C. Zou, X. S. Huang, L. J. Zhang, Y. Yang, X. A. Chen, S. M. Huang, Nanoscale, 2013, 5, 1638-1648.

[51] X. Sheng, L. Wang, Y. P. Luo, D. R. Yang, Nanoscale Res. Lett., 2011, 6, 562.

[52] K. T. Yong, I. Roy, R. Hu, H. Ding, H. X. Cai, J. Zhu, X. H. Zhang, E. J. Bergey, P. N. Prasad, Integr. Biol., 2010, 2, 121-129.

[53] S. H. Jeong, B. S. Lee, S. J. Ahn, K. H. Yoon, Y. H. Seo, Y. M. Choi, B. H. Ryu, Energy Environ. Sci., 2012, 5, 7539-7542.

[54] K. Nose, Y. Soma, T. Omata, S. Otsuka-Yao-Matsuo, Chem. Mater., 2009, 21, 2607-2613.

[55] W. J. Zhang, X. H. Zhong, Inorg. Chem., 2011, 50, 4065-4072.

[56] J. B. Zhang, W. P. Sun, L. P. Yin, X. S. Miao, J. Mater. Chem. C, 2014, 2, 4812-4817.

[57] K. Nose, T. Omata, S. Otsuka-Yao-Matsuo, J. Phys. Chem. C, 2009, 113, 3455-3460.

[58] H. Z. Zhong, Y. C. Li, M. F. Ye, Z. Z. Zhu, C. H. Yang, Y. F. Li, Nanotechnology, 2007, 18, 0256021/1-0256021/6.

[59] B. Li, Y. Xie, J. Huang, Y. Qian, Adv. Mater., 1999, 11, 1456-1459.

[60] A. D. Kergommeaux, A. Fiore, N. Bruyant, F. Chandezon, P. Reiss, A. Pron, R. D. Bettignies, J. Faure-vincent, Sol. Energy Mater. Sol. Cells, 2011, 95, S39-S43.

[61] H. Z. Zhong, Z. B. Wang, E. Bovero, Z. H. Lu, F. C. J. M. V. Veggel, G. D. Scholes, J. Phys. Chem. C, 2011, 115, 12396-12402.

[62] A. J. Wooten, D. J. Werder, D. J. Williams, J. L. Casson, J. A. Hollingsworth, J. Am. Chem. Soc., 2009, 131, 16177-16188.

[63] M. E. Norako, R. L. Brutchey, Chem. Mater., 2010, 22, 1613-1615.

[64] E. Cassette, T. Pons, C. Bouet, M. Helle, L. Bezdetnaya, F. Marchal, B.
Dubertre, Chem. Mater., 2010, 22, 6117-6124.

[65] N. Xiao, L. Zhu, K. Wang, Nanoscale, 2012, 4, 7443-7477.

[66] Q. Y. Lu, J. Q. Hu, K. B. Tang, Y. T. Qian, G. Zhou, X. M. Liu, Inorg. Chem., 2000, 39, 1606-1607.

[67] J. Tang, S. Hinds, S. O. Kelley, E. H. Sargent, Chem. Mater., 2008, 20, 6906-6910.

[68] J. P. Xiao, Y. Xie, Y. J. Xiong, R. Tang, Y. T. Qian, J. Mater. Chem., 2001, 11, 1417-1420.

[69] J. L. Cholula-Díaz, J. Barzola-Quiquia, C. Kranert, T. Michalsky, P. Esquinazi, M. Grundmann, H. Krautscheid, Phys. Chem. Chem. Phys., 2014, 16, 21860-21866.

[70] T. Ogawa, T. Kuzuya, Y. Hamanaka, K. Sumiyama, J. Mater. Chem., 2010, 20, 2226-2231.

[71] X. S. Tang, K. Yu, Q. H. Xu, E. S. G. Choo, G. K. L. Goh, J. M. Xue, J. Mater. Chem., 2011, 21, 11239-11243.

[72] W. M. Du, X. F. Qian, J. Yin, Q. Gong, Chem. Eur. J., 2007, 13, 8840-8846.

[73] C. J. Stolle, M. G. Panthani, T. B. Harvey, V. A. Akhavan, B. A. Korgel, ACS Appl. Mater. Interfaces, 2012, 4, 2757-2761.

[74] L. A. Juhaiman, L. Scoles, D. Kingston, B. Patarachao, D. Wang, F. Benseb, Green Chem., 2010, 12, 1248-1252.

[75] R. Boonsin, A. Barros, F. Donat, D. Boyer, G. Chadeyron, R. Schneider, P. Boutinaud, R. Mahiou, ACS photonics, 2017, 5, 462-470.

[76] A. Shavel, D. Cadavid, M. Ibanez, A. Carrete, A. Cabot, J. Am. Chem. Soc., 2012, 134, 1438-1441.

[77] T. Kameyama, T. Osaki, K. I. Okazaki, T. Shibayama, A. Kudo, S. Kuwabata, T. Torimoto, J. Mater. Chem., 2010, 20, 5319-5324.

[78] M. Cao, Y. Shen, J. Cryst. Growth, 2011, 318, 1117-1120.

[79] X. T. Lu, Z. B. Zhuang , Q. Peng, Y. D. Li, Chem. Commun., 2011, 47, 3141-3143.

[80] L. Li, A. Pandey, D. J. Werder, J. Am. Chem. Soc., 2011, 133, 1176-1179.

[81] B. K. Chen, S. Chang, D. Y. Li, L. L. Chen, Y. T. Wang, T. Chen, B. S. Zou, H. Z. Zhong, A. L. Rogach, Chem. Mater., 2015, 27, 5949-5956.

[82] X. J. Wu, X. Huang, X. Y. Qi, H. Li, B. Li, H. Zhang, Angew. Chem., 2014, 53, 8929-8933.

[83] W. V. D. Stam, A. C. Berends, F. T. Rabouw, T. Willhammar, X. X. Ke, J. D. Meeldijk, S. Bals, C. D. M. Donega, Chem. Mater., 2015, 27, 621-628.

[84] W. V. D. Stam, A. P. Gantapara, Q. A. Akkerman, G. Soligno, J. D. Meeldijk, R. V. Roij, M. Dijkstra, C. D. M. Donega, Nano Lett., 2014, 14, 1032-1037.

[85] H. B. Li, M. Zanella, A. Genovese, M. Povia, A. Falqui, C. Giannini, L. Manna, Nano Lett., 2011, 11, 4964-4970.

[86] W. V. D. Stam, Q. A. Akkerman, X. X. Ke, M. A. V. Huis, S. Bals, C. D. M. Donega, Chem. Mater., 2014, 27, 283-291.

[87] V. Lesnyak, C. George, A. Genovese, M. Prato, A. Casu, S. Ayyappan, A. Scarpellin, L. Manna, ACS Nano, 2014, 8, 8407-8418.

[88] A. J. Demello, Nature, 2006, 442, 394-402.

[89] A. Yashina, I. Lignos, S. Stavrakis, J. Choo, A. J. deMello, J. Mater. Chem. C, 2016, 4, 6401-6408.

[90] A. Prudnikau, A. Chuvilin, M. Artemyev, J. Am. Chem. Soc., 2013, 135, 14476-14479.

[91] H. Z. Zhong, Z. L. Bai, B. S. Zou, J. Phys. Chem. Lett., 2012, 3, 3167-3175.

[92] W. G. J. H. M. van Sark, P. L. T. M. Frederix, A. A. Bol, H. C. Gerritsen, Chem. Phys. Chem., 2002, 3, 871-879.

[93] S. L. Castro, S. G. Bailey, R. P. Raffaelle, K. K. Banger. A. F. Hepp, J. Phys. Chem. B, 2004, 108, 12429-12435.

[94] J. Zhang, R. G. Xie, W. S. Yang, Chem. Mater., 2011, 23, 3357-3361.

[95] Z. A. Tan, Y. Zhang, C. Xie, H. P. Su, J. Liu, C. F. Zhang, N. Dellas, S. E. Mohney, Y. Q. Wang, J. K. Wang, J. Xu, Adv. Mater., 2011, 23, 
3553-3558.

[96] Z. H. Lin, Z. P. Liu, H. Zhang, X. G. Su, Analyst,, 2015, 140, 1629-1636

[97] B. D. Mao, C. H. Chuang, F. Lu, L. X. Sang, J. J. Zhu, C. Burda, J. Phys. Chem. C, 2012, 117,648-656.

[98] T. Torimoto, S. Ogawa, T. Adachi, T. Kameyama, K. Okazaki, T. Shibayama, A. Kudo, S. Kuwabata, Chem. Commun., 2010, 46, 2082-2084.

[99] A. D. P. Leach, X. Shen, A. Faust, M. C. Cleveland, A. D. L. Croix, U. Banin, S. T. Pantelides, J. E. Macdonald, J. Phys. Chem. C, 2016, 120, 5207-5212.

[100] O. Yarema, M. Yarema, D. Bozyigit, W. M. M. Lin, V. Wood, ACS Nano, 2015, 9, 11134-11142.

[101] W. D. Rice, H. McDaniel, V. I. Klimov, S. A. Crooker, J. Phys. Chem. Lett., 2014, 5, 4105-4109.

[102] C. Steinhagen, V. A. Akhavan, B. W. Goodfellow, M. G. Panthani, J. T. Harris, V. C. Holmberg, B. A. Korgel, ACS Appl. Mater. Interfaces, 2011, 3, 1781-1785.

[103] V. A. Akhavan, B. W. Goodfellow, M. G. Panthani, D. K. Reid, D. J. Hellebusch, T. Adachi, B. A. Korgel, Energy Environ. Sci., 2010, 3, 1600-1606.

[104] Z. P. Liu, K. B. Tang, D. Wang, L. L. Wang, Q. Y. Hao, Nanoscale, 2013, 5, 1570-1575.

[105] M. H. Abib, Y. J. Chang, X. D. Yao, G. P. Li, D. B. Yu, Y. Jiang, Nano, 2017, 12, 1750014 .

[106] Q. J. Guo, G. M. Ford, H. W. Hillhouse, R. Agrawal, Nano lett., 2009, 9, 3060-3605.

[107] C. Steinhagen, M. G. Panthani, V. Akhavan, B. Goodfellow, B. Koo, B. A. Korgel, J. Am. Chem. Soc., 2009, 131, 12554-12555.

[108] Q. J. Guo, G. M. Ford, W. C. Yang, B. C. Walker, E. A. Stach, H. W. Hillhouse, R. Agrawal, J. Am. Chem. Soc., 2010, 132, 17384-17386.

[109] Q. W. Tian, X. F. Xu, L. B. Han, M. H. Tang, R. J. Zou, Z. G. Chen, M. H. Yu, J. M. Yang J. Q. Hu, CrystEngComm., 2012, 14, 3847-3850.

[110] D. V. Talapin, C. B. Murray, Science, 2005, 310, 86-89.

[111] J. J. Urban, D. V. Talapin, E. V. Shevchenko, C. R. Kagan, C. B. Murray, Nat. Mater., 2007, 6, 115-121.

[112] G. Konstantatos, I. Howard, A. Fischer, S. Hoogland, J. Clifford, E. Klem, L. Levina, E. H. Sargent, Nature, 2006, 442, 180-183.

[113] J. E. Murphy, M. C. Beard, A. J. Nozik, J. Phys. Chem. B, 2006, 110, 25455-25461.

[114] M. V. Jarosz, V. J. Porter, B. R. Fisher, M. A. Kastner, M. G. Bawendi, Phys. Rev. B, 2004, 70, 195327/1-195327/12.

[115] D. Yu, C. J. Wang, P. Guyot-Sionnest, Science, 2003, 300, 1277-1280.

[116] S. Ye, F. Xiao, Y. X. Pan, Y. Y. Ma, Q. Y. Zhang, Mater. Sci. Eng. R, 2010, 71, 1-34.

[117] C. C. Lin, R. S. Liu, J. Phys. Chem. Lett., 2011, 2, 1268-1277.

[118] B. K. Chen, H. Z. Zhong, M. X. Wang, R. B. Liu, B. S. Zou, Nanoscale, 2013, 5, 3514-3519.

[119] B. K. Chen, Q. C. Zhou, J. F. Li, F Zhang, R. B. Liu, H. Z. Zhong, B. S. Zou, Opt. Express, 2013, 21, 10105-10110.

[120] L. C. Peng, D. Z. Li, Z. L. Zhang, K. K. Huang, Y. Zhang, Z. Shi, R. G. Xie, W. S. Yang, Nano Res., 2015, 8, 3316-3331.

[121] B. Huang, Q. D, N. Z. Zhuo, Q. S. Jiang, F. H. Shi, H. B. Wang, H. C. Zhang, C. Liao, Y. P. Cui, J. Y. Zhang, J. Appl. Phys., 2014, 116, 094303/1-094303/5.

[122] S. P. Hong, H. K. Park, J. H. Oh, H. Yang, Y. R. Do, J. Mater. Chem., 2012, 22, 18939-18949.

[123] W. S. Song, H. Yang, Chem. Mater., 2012, 24, 1961-1967.

[124] H. C. Yoon, J. H. Oh, M. Ko, H. Yoo, Y. R. Do, ACS Appl. Mater. Interfaces, 2015, 7, 7342-7350.
[125] W. S. Song, S. H. Lee, H. Yang, Opt. Mater. Express, 2013, 3, 1468-1473.

[126] A. Aboulaich, M. Michalska, R. Schneider, A. Potdevin, J. Deschamps, R. Deloncle, G. Chadeyron, R. Mahiou, ACS Appl. Mater. Interfaces, 2014, 6, 252-258.

[127] S. Y. Liu, W. D. Na, S. Pang, F. P. Shi, X. G. Su, Analyst, 2014, 139, 3048-3054.

[128] S. Y. Liu, J. J. Hu, X. G. Su, Analyst, 2012, 137, 4598-4604.

[129] X. Gao, Z. P. Liu, Z. H. Lin, X. G. Su, Analyst, 2014, 139, 831-836.

[130] Z. H. Lin, X. F. Fei, Q. Ma, X. Gao, X. G. Su, New J. Chem., 2014, 38, 90-96.

[131] B. B. Lin, X. Z. Yao, Y. H. Zhu, J. H. Shen, X. L. Yang, C. Z. Li, RSC Adv., 2014, 4, 20641-20648.

[132] W. S. Guo, X. L. Sun, O. Jacobson, X. F. Yan, K. Min, A. Srivatsan, G. Niu, D. O. Kiesewetter, J. Chang, X. Y. Chen, ACS Nano, 2015, 9, 488-495.

[133] G. X. Lv, W. S. Guo, W. Zhang, T. B. Zhang, S. Y. Li, S. Z. Chen, A. S. Eltahan, D. L. Wang, Y. Wang, J. C. Zhang, P. C. Wang, J. Chang, X. J. Liang, ACS Nano, 2016, 10, 9637-9645.

[134] X. B. Chen, S. H. Shen, L. J. Guo, S. S. Mao, Chem. Rev., 2010, 110, 6503-6570.

[135] I. Tsuji, H. Kato, H. Kobayashi, A. Kudo, J. Phys. Chem. B, 2005, 109, 7323-7329.

[136] A. Kudo, M. Sekizawa, Chem. Commun., 2000, 1371-1372.

[137] A. Kudo, M. Sekizawa, Catal. Lett., 1999, 58, 241-243.

[138] I. Tsuji, A. Kudo, Photochem. Photobiol., 2003, 156, 249-252.

[139] X. S. Tang, Q. L. Tay, Z. Chen, Y. Chen, G. K. L. Goh, J. Xue, New J. Chem., 2013, 37, 1878-1882.

[140] M. G. Walter, E. L. Warren, J. R. McKone, S. W. Boettcher, Q. X. Mi, E. A. Santori, N. S. Lewis, Chem. Rev., 2010, 110, 6446-6473.

[141] R. S. Wang, X. X. Xu, Y. Zhang, Z. M. Chang, Z. C. Sun, W. F. Dong, Nanoscale, 2015, 7, 11082-11092.

[142] Q. Liu, F. R. Cao, F. L. Wu, S. M. Chen, J. Xiong, L. Li, ACS Appl. Mater. Interfaces, 2016, 8, 26235-26243.

[143] H. Neumann, W. Hörig, V. Savelev, J. Lagzdonis, B. Schumann, G. Kuhn, Thin Solid Films, 1981, 79, 167-171.

[144] C. Zeng, H. W. Huang, Y. R. Hu, F. Dong, Y. H. Zhang, Y. M. Hu, ACS Appl. Mater. Interfaces, 2017, 9, 27773-27783.

[145] M. Kruszynska, H. Borchert, J. Parisi, J. Kolny-Olesiak, J. Am. Chem. Soc., 2010, 132, 15976-15986.

[146] Z. L. Bai, W. Y. Ji, D. B Han, L. L. Chen, B. K. Chen, H. B. Shen, B. S. Zou, H. Z. Zhong, Chem. Mater., 2016, 28, 1085-1091.

[147] J. H. Kim, H. Yang, Chem. Mater., 2016, 28, 6329-6335.

[148] F. Li, C. Y. Guo, R. Pan, R. Pan, Y. Y. Zhu, Y. Lai, J. Wang, X. Jin, Q. Zhang, Y. L. Song, Z. P. Chen, Q. H. Li, Opt. Mater. Express, 2018, 8, 314-323.

[149] D. B. Choi, S. Kim, H. C. Yoon, M. Ko, H. Yang, Y. R. Do, J. Mater. Chem. C, 2017, 5, 953-959.

[150] Z. Y. Liu, A. W. Tang, Y. H. Xie, Z. Y. Guan, Y. Chen, F. Tang, Org. Electron., 2017, 45, 20-25.

[151] Y. Zhang, C. Xie, H. P. Su, J. Liu, S. Pickering, Y. Wang, W. W. Yu, J. K. Wang, Y. D. Wang, J. Hahm, N. Dellas, S. E. Mohney, J. Xu, Nano Lett., 2010, 11, 329-332.

[152] H. Ferhati, F. Djeffal, Opt. Mater., 2018, 76, 393-399.

[153] A. H. Cheshme Khavar, A. R. Mahjoub, N. Taghavinia, Sol. Energy, 2017, 157, 581-586.

[154] A. Gueddim, N. Bouarissa, A. Naas, F. Daoudi, N. Messikine, Appli. Physi. A, 2018, 124, 199.

[155] C. de Mello Donegá, P. Liljeroth, D. Vanmaekelbergh, Small, 2005, $1,1152-1162$.

[156] G. Demazeau, J. Mater. Sci., 2008, 43, 2104-2114.

[157] H. Du, Y. N. Liu, C. C. Shen, A. W. Xu, Chin. J. Catal., 2017, 38, 
1295-1306

[158] J. Z. Su, T. Zhang, L. Wang, J. W. Shi, Y. B. Chen, Chin. J. Catal.,
2017, 38, 489-497.

[159] S. Ma, X. M. Xu, J. Xie, X. Li, Chin. J. Catal., 2017, 38, 1970-1980.

\title{
I-III-VI 族半导体纳米晶：合成, 性质及应用
}

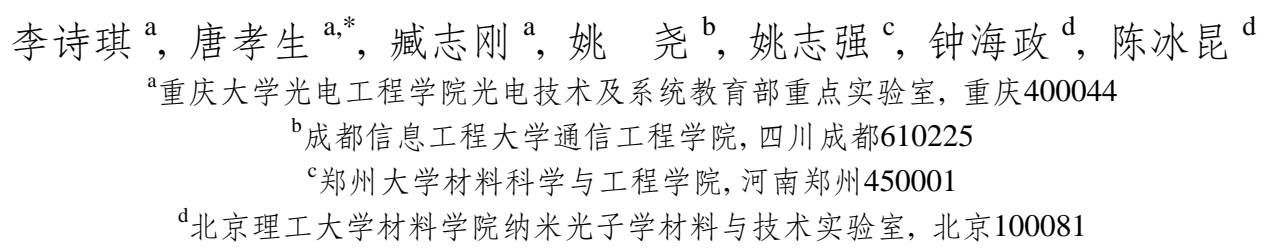

\begin{abstract}
摘要: 半导体纳米晶具有独特的量子限域效应以及新颖的尺寸和形貌依赖特性, 已被证实是在低成本高性能光伏器件、光 致及电致发光二极管、生物成像、光催化等领域非常具有潜力的新型材料. 其中, II-VI 族与 I-III-VI 族半导体纳米晶由于 其优异的性能在过去的数十年中引起了广泛的关注. 过去数十年对于 II-VI 族半导体纳米晶的研究已经十分成熟, 然而几 乎所有的传统 II-VI 族半导体纳米晶都含有对环境有害的元素, 对人体和环境造成不可逆转的伤害, 从而限制了 II-VI 族半 导体纳米晶的进一步应用. 与二元 II-VI 族纳米晶相比, 大部分三元 I-III-VI 族纳米晶不含镉和铅等重金属元素,因而具有 低毒性的特点, 并且其带隙窄、吸光收系数大、斯托克斯位移大、自吸收小以及发光波长在近红外区, 所以有望使其成为 新一代荧光纳米晶材料. 例如, CuInS 2 的带隙为 $1.53 \mathrm{eV}$, 与太阳光谱匹配且其吸光系数较大, 在 $10^{-5} \mathrm{~cm}^{-1}$ 左右, 从而使其成 为制备太阳能电池的一种优秀材料. 另一方面, I-III-VI 族纳米晶在可见光和近红外范围内呈现与尺寸相关的发光, 它们的 苂光量子产率在包覆 ZnS 壳后可超过 50\%, 因而在照明, 显示和生物成像领域具广泛应用的潜力. 水溶性的 I-III-VI 族量 子点粒径尺寸可以小于 $10 \mathrm{~nm}$, 可以减小纳米颗粒通过肾清除的淘汰率, 并且具有高荧光性能和耐光性的特点, 因此成为 进行生物成像工作的优秀材料. 与此同时, I-III-VI 族纳米晶在光催化领域也展现了巨大的发展前景.

本综述主要关注 I-III-VI 族纳米晶的合成, 性质及应用. 首先, 我们概述了不同的化学合成方法, 并列举讨论了一些经 典的工作, 根据纳米晶的种类分类统计了主要合成方法、形貌及尺寸. 第二部分, 我们讨论了它们的光物理和电子特性, 解 释了纳米晶的“donor-acceptor pair”(DAP) 结合机理, 概述了 I-III-VI 族纳米晶的磁光现象. 接下来, 我们概述了 I-III-VI 族 纳米晶主要的应用领域, 着重总结了在太阳能电池领域、半导体发光二极管领域、生物成像领域以及光催化制氢领域的研 究进展. 最后, 我们会讨论半导体纳米晶的应用前景, 以及它的机遇和挑战.
\end{abstract}

关键词: I-III-VI 族纳米晶; 合成方法; 太阳能电池; 发光二极管; 生物成像; 光催化

收稿日期: 2018-01-21. 接受日期: 2018-02-12. 出版日期: 2018-04-05.

*通讯联系人. 电话: 18423440836; 电子信箱: xstang@cqu.edu.cn

本文的电子版全文由Elsevier出版社在ScienceDirect上出版(http://www.sciencedirect.com/science/journal/18722067). 